\title{
The Anterior Cingulate Cortex May Enhance Inhibition of Lateral Prefrontal Cortex Via m2 Cholinergic Receptors at Dual Synaptic Sites
}

\author{
Maria Medalla ${ }^{1,2,3}$ and Helen Barbas ${ }^{1,2,3}$ \\ ${ }^{1}$ Neural Systems Laboratory and Departments of ${ }^{2}$ Health Sciences and ${ }^{3}$ Anatomy and Neurobiology, Boston University and School of Medicine, Boston, \\ Massachusetts 02215
}

The anterior cingulate cortex (ACC) and dorsolateral prefrontal cortices (DLPFC) share robust excitatory connections. However, during rapid eye movement (REM) sleep, when cortical activity is dominated by acetylcholine, the ACC is activated but DLPFC is suppressed. Using pathway tracing and electron microscopy in nonhuman primates (Macaca mulatta), we tested the hypothesis that the opposite states may reflect specific modulation by acetylcholine through strategic synaptic localization of muscarinic $\mathrm{m} 2$ receptors, which inhibit neurotransmitter release presynaptically, but are thought to be excitatory postsynaptically. In the ACC pathway to DLPFC (area 32 to area 9), $\mathrm{m} 2$ receptors predominated in ACC axon terminals and in more than half of the targeted dendrites of presumed inhibitory neurons, suggesting inhibitory cholinergic influence. In contrast, in a pathway linking the DLPFC area 46 to DLPFC area 9, postsynaptic m2 receptors predominated in targeted spines of presumed excitatory neurons, consistent with their mutual activation in working memory. These novel findings suggest that presynaptic and postsynaptic specificity of $\mathrm{m} 2$ cholinergic receptors may help explain the differential engagement of ACC and DLPFC areas in REM sleep for memory consolidation and synergism in awake states for cognitive control.

\section{Introduction}

The anterior cingulate cortex (ACC) and dorsolateral prefrontal cortices (DLPFC) are robustly linked but have distinct roles in cognitive control (for review, see Barbas et al., 2002; Rushworth et al., 2011). The two regions also differ markedly in their physiologic state during rapid eye movement (REM) sleep: after a period of silence, the ACC is reactivated, whereas the DLPFC remains suppressed (for review, see Muzur et al., 2002). The question arises about the circuit mechanism for the opposite activation pattern, in view of the massive excitatory glutamatergic projections from ACC (area 32) that innervate widely the DLPFC (Barbas et al., 1999). We previously found that ACC axons form large synapses with a subset of inhibitory neurons in DLPFC, accounting for $\sim 20-30 \%$ of all synapses in the pathway (Medalla and Barbas, 2009, 2010). However, this ACC pathway innervates mostly calbindin inhibitory neurons, which form synapses with distal dendrites of adjacent excitatory (pyramidal) neurons, eliciting weak inhibition (for review, see DeFelipe,

Received May 15, 2012; revised Aug. 13, 2012; accepted Sept. 9, 2012.

Author contributions: M.M. and H.B. designed research; M.M. and H.B. performed research; M.M. analyzed data; M.M. and H.B. wrote the paper.

This work was supported by National Institutes of Health Grants from the National Institute of Neurological Disorders and Stroke R01NS024760 and the National Institute of Mental Health R01MH057414 and by Center of Excellence for Learning in Education, Science, and Technology (a National Science Foundation Science of Learning Center) Grant SBE-0354378. We thank Marcia Feinberg and Clare Timbie for technical assistance, Drs. Claus Hilgetag and Basilis Zikopoulos for consultation with statistics, Dr. John Fiala for help with 3D reconstruction, Drs. Michael Hasselmo, Alan Peters, and Jennifer Luebke for input, and Dr. Ron Killiany for help with imaging.

Correspondence should be addressed to Helen Barbas, Boston University, 635 Commonwealth Avenue, Room 431, Boston, MA 02215. E-mail: barbas@bu.edu.

DOI:10.1523/JNEUROSCI.2339-12.2012

Copyright $\odot 2012$ the authors $\quad 0270-6474 / 12 / 3215611-15 \$ 15.00 / 0$
1997). This type of inhibition is optimally suited to reduce noise in DLPFC during cognitive operations that require attention (Wang et al., 2004b). However, even if recruited during REM sleep, it is unlikely that this limited ACC-mediated inhibition can silence DLPFC activity.

A more likely possibility is that the opposite states in ACC and DLPFC are mediated through the cholinergic neuromodulatory system, which is highly active during REM sleep (for review, see Kahn and Hobson, 2005; Walker et al., 2005). Acetylcholine binds to two main classes of receptors in the cortex, nicotinic and muscarinic. Muscarinic receptors, specifically the $\mathrm{m} 1$ subtype, are the predominant cholinergic receptors in the cortex. Activation of $\mathrm{ml}$ receptors has primarily depolarizing effects on pyramidal neurons, in which they are mostly localized postsynaptically on spines (for review, see McCormick, 1989; Levey, 1996). Cholinergic projections innervate the ACC in all layers and are considerably denser than in DLPFC (Mesulam et al., 1984; Lewis, 1991; Ghashghaei and Barbas, 2001), a pattern that may explain the differences in activation in the two regions during REM sleep. However, this scenario does not explain why, once activated, the massive excitatory projections from ACC do not then activate excitatory postsynaptic sites in DLPFC.

Acetylcholine also has suppressive effects in the cortex, mediated through stimulation of presynaptic muscarinic receptors that decrease release of excitatory neurotransmitter (for review, see Lucas-Meunier et al., 2003; Hasselmo, 2006) or through postsynaptic activation of inhibitory neurons (McCormick and Prince, 1985; Pitler and Alger, 1992; Kawaguchi, 1997; McQuiston and Madison, 1999). Among the diverse cholinergic receptors, the muscarinic $\mathrm{m} 2$ subtype is found mostly at presynaptic 
boutons of cortical glutamatergic axons and also at postsynaptic sites of a subset of GABAergic neurons (Levey et al., 1991; Mrzljak et al., 1993; Erisir et al., 2001). We reasoned that $\mathrm{m} 2$ receptors in the ACC pathway may enhance suppression in DLPFC, by dual mechanisms: through presynaptic $\mathrm{m} 2$ receptors on ACC boutons that form synapses in DLPFC and through postsynaptic $\mathrm{m} 2$ receptors on dendrites of targeted inhibitory neurons in DLPFC. We provide evidence consistent with this hypothesis.

\section{Materials and Methods}

\section{Surgical procedures and injection of neural tracers}

Injections of neural tracers were made in normal rhesus monkeys (Macaca mulatta; $2-3$ years of age of both sexes; $n=3$; two females, one male; five injection sites), using MRI, surgical, and tissue processing procedures described previously (Medalla et al., 2007; Medalla and Barbas, 2009). Animals were obtained from the New England Primate Research Center (NEPRC), and protocols were approved by the Institutional Animal Care and Use Committee at NEPRC, Harvard Medical School, and Boston University in accordance with the NIH Guide for the Care and Use of Laboratory Animals. Procedures were designed to minimize animal suffering and reduce the number of animals used.

Injection sites were based on stereotaxic coordinates calculated from MRI scans taken before surgery, using the midline and betadine-filled ear-bar tips as reference points. We injected the bidirectional tracers biotinylated dextran amine (BDA), fluoroemerald (FE; dextran fluorescein), fluororuby (FR; dextran tetramethylrhodamine), or lucifer yellow (LY; dextran lucifer yellow; Invitrogen) using a microsyringe (5 or $10 \mu$ l; Hamilton) mounted on a microdrive. All tracers were dextran amines of $10 \mathrm{kDa}$ molecular weight optimized for anterograde transport to label the entire extent of axons and terminals (boutons) (Dolleman-Van der Weel et al., 1994). They also label neurons retrogradely, but labeling is sporadic and restricted to the cell bodies and proximal dendrites and does not appear to enter axon collaterals (Veenman et al., 1992; Reiner et al., 2000; our personal observations). In each case, the dye was diluted to $10 \mathrm{mg} / \mathrm{ml}$ in distilled water and delivered in two to four penetrations (spaced 0.5 $\mathrm{mm}$ apart; $2 \mu$ lof dye per penetration) at a depth of $1.2-1.6 \mathrm{~mm}$ below the pial surface. The tracer injection sites in prefrontal areas 46 and 32 (Fig. 1) are summarized as follows: tracer injections in area 46, case BIr (female, 3 years old, left hemisphere, FR) and case BH (female, 3 years old, left hemisphere, BDA); tracer injections in area 32, case BI (female, 3 years old, right hemisphere, BDA), case BIe (female, 3 years old, right hemisphere, FE), and case BLy (male, 3 years old, right hemisphere, LY).

\section{Perfusion and tissue processing}

After a survival period of $18 \mathrm{~d}$, the animals were given an overdose of sodium pentobarbital $(>50 \mathrm{mg} / \mathrm{kg})$ until a deep level of anesthesia was achieved and then transcardially perfused with freshly depolymerized $4 \%$ paraformaldehyde and $0.2 \%$ glutaraldehyde (EM grade; Ladd Research Industries) in $0.1 \mathrm{~m}$ phosphate buffer (PB) with $0.9 \% \mathrm{NaCl}$, pH 7.4, at $37^{\circ} \mathrm{C}$. The brains were removed from the skull, cryoprotected in graded solutions of sucrose $(10-30 \%)$, frozen in $-70^{\circ} \mathrm{C}$ isopentane (Rosene et al., 1986), and cut on a freezing microtome in the coronal plane at $50 \mu \mathrm{m}$. To preserve the ultrastructure, tissue was stored in anti-freeze solution (30\% ethylene glycol, $30 \%$ glycerol, in 0.05 м PB, pH 7.4 with $0.05 \%$ azide) at $-20^{\circ} \mathrm{C}$ until use.

Single and double immunohistochemical labeling for bright-field micros$c o p y$. To view and map tracer-labeled fibers and $\mathrm{m} 2$ receptors at the light microscope, we used immunohistochemical techniques using the avidin-biotin $(\mathrm{AB})$ with horseradish peroxidase (HRP) method as described previously (Medalla and Barbas, 2010). Free-floating sections were rinsed in $0.01 \mathrm{M}$ PBS, incubated in $0.05 \mathrm{~m}$ glycine $\left(1 \mathrm{~h}, 4^{\circ} \mathrm{C}\right)$, and blocked in 5\% normal goat serum (NGS) and 5\% bovine serum albumin (BSA) with $0.2 \%$ Triton X-100 $\left(1 \mathrm{~h}, 25^{\circ} \mathrm{C}\right)$. For cases with BDA injections, sections were incubated for $1 \mathrm{~h}$ in AB-HRP solution (1:100 in PBS with $0.1 \%$ Triton X-100; Vectastain PK-6100 ABC Elite kit; Vector Laboratories), rinsed, and then processed using the peroxidase-catalyzed polymerization of diaminobenzidine (DAB substrate kit, 2-3 min; Vector Laboratories). For cases with fluorescent tracers FE, FR, and LY, sections were processed for immunohistochemistry using antibodies against the fluorophores to view label at the light microscope. Sections were first incubated in $\mathrm{AB}$ blocking reagent ( $\mathrm{AB}$ blocking kit; Vector Laboratories) to prevent cross-reaction with $\mathrm{BDA}$, blocked in serum (as above), and then incubated overnight $\left(4^{\circ} \mathrm{C}\right)$ in the rabbit polyclonal primary antibodies against FE (anti-fluorescein/Oregon Green), FR (anti-tetramethylrhodamine), or LY (anti-lucifer yellow; 1:800; Invitrogen). Sections were then incubated for $2 \mathrm{~h}$ in biotinylated secondary goat anti-rabbit IgG (1:200; Vector Laboratories), followed by $1 \mathrm{~h}$ in AB-HRP solution, and then processed for DAB.

To label $\mathrm{m} 2$ receptors, sections were incubated overnight in a rat monoclonal antibody against the i3 loop of the muscarinic acetylcholine $\mathrm{m} 2$ receptor subtype fusion protein $\left(1: 500,4^{\circ} \mathrm{C}\right.$; clone M2-2-B3; Millipore), as described previously (Mrzljak et al., 1993; Levey et al., 1995). After rinsing, sections were incubated for $2 \mathrm{~h}$ in biotinylated goat anti-rat IgG (1:200; Vector Laboratories) and then $1 \mathrm{~h}$ in AB-HRP solution, followed by $\mathrm{DAB}$ processing. We also used double-labeling techniques for bright-field microscopy to visualize $\mathrm{m} 2$ receptor label along with neural tracers using two precipitation methods that yield distinct reaction products. Sections were first processed for tracers with DAB (as above) and then incubated in AB block and serum blocking solution (as above) to prevent cross-reaction with the subsequent labeling of $\mathrm{m} 2$ receptors. Sections were then incubated in the primary antibody against $\mathrm{m} 2$, followed by biotinylated goat anti-rat IgG and then AB-HRP, as described above. Sections were then processed using the SG substrate kit (2-3 min; Vector Laboratories), which precipitates into a blue-gray reaction product, discernible from the brown DAB reaction product (Fig. $1 D, E)$.

Double immunohistochemical labeling for fluorescence microscopy. To assess the extent of colocalization of tracer and $\mathrm{m} 2$ receptors in prefrontal axons, we used secondary antibodies conjugated to red (Alexa Fluor 568) or green (Alexa Fluor 488) fluorescent probes. Sections were treated with glycine, blocked with serum, and incubated in primary antibody against $\mathrm{m} 2$ (as above). To view BDA label together with $\mathrm{m} 2$ receptors under fluorescence, sections were coincubated overnight in fluorescentconjugated streptavidin and secondary goat anti-rat IgG (1:200; Invitrogen) of complementary colors. In cases with FE or FR fluorescent tracers, $\mathrm{m} 2$ was labeled with the complementary fluorescent probe. In some sections, tracer signal was enhanced using anti-FE or anti-FR primary antibodies (as above) with the color-matched fluorescent-conjugated secondary anti-rabbit IgG (1:200, Alexa Fluor 488 for FE, Alexa Fluor 568 for FR; Invitrogen).

After processing, sections were mounted, dried, and coverslipped with Entellan (EMD Chemicals) for sections processed for light microscopy and Krystalon (EMD Chemicals) or Prolong anti-fade (Invitrogen) for sections processed for fluorescence microscopy. Adjacent sections were counterstained with thionin (Sigma) to delineate areas and layers.

Double preembedding immunohistochemistry for electron microscopy. For viewing prefrontal pathways labeled with tracers and $\mathrm{m} 2$ receptors at the electron microscope (EM), we used dual preembedding immunohistochemistry using DAB staining and gold-conjugated secondary antibodies. Sections were processed as above but with lower $(0.025 \%)$ Triton $\mathrm{X}-100$ for all steps. Sections were incubated overnight in the appropriate combination of primary antibodies (1:500 rat anti-m2 for BDA tissue; 1:500 rat anti-m2 with 1:800 rabbit anti-FE, FR, or LY). Sections with FE, FR, or LY label were incubated in secondary biotinylated goat anti-rabbit IgG (as above). After rinses in PBS, sections were incubated in goldconjugated secondary goat anti-rat IgG $\left(1: 50\right.$, overnight at $4^{\circ} \mathrm{C}$, particle diameter of $5 \mathrm{~nm}$; Ted Pella) or FAB fragment $\left(1: 200\right.$ for $3 \mathrm{~h}$ at $25^{\circ} \mathrm{C}$, particle diameter of $1.4 \mathrm{~nm}$; Nanoprobes) diluted in PBS with $1 \%$ NGS, $1 \%$ BSA-c (acetylated BSA; Aurion), and $0.1 \%$ gelatin. The sections were rinsed quickly in PBS, postfixed in $2 \%$ glutaraldehyde $\left(5 \mathrm{~min}, 25^{\circ} \mathrm{C}\right)$, followed by rinses in glycine ( $5 \mathrm{~min}$ ), water $(2 \mathrm{~min})$, and $0.02 \mathrm{M}$ sodium citrate buffer, $\mathrm{pH} 7(2 \times 5 \mathrm{~min})$. Gold labeling was then intensified with a silver enhancement kit (IntenSE M kit, GE Healthcare; or HQ Silver enhancement kit, Nanoprobes) using optimal incubation times (6-12 min) to yield silver-enhanced gold particles of larger than $15 \mathrm{~nm}$. Sections were rinsed in sodium citrate buffer $(5 \mathrm{~min})$ and then in $0.1 \mathrm{M} \mathrm{PB}$ $(3 \times 5 \mathrm{~min})$. Sections were incubated in $\mathrm{AB}-\mathrm{HRP}$ (in $0.1 \mathrm{M} \mathrm{PB}$ ) and 
A
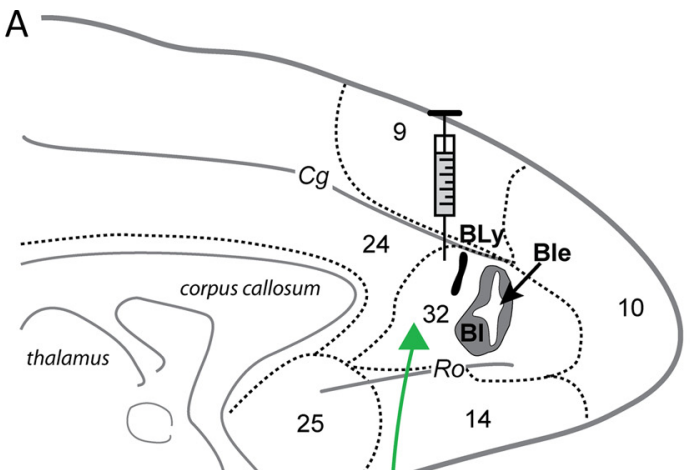

B

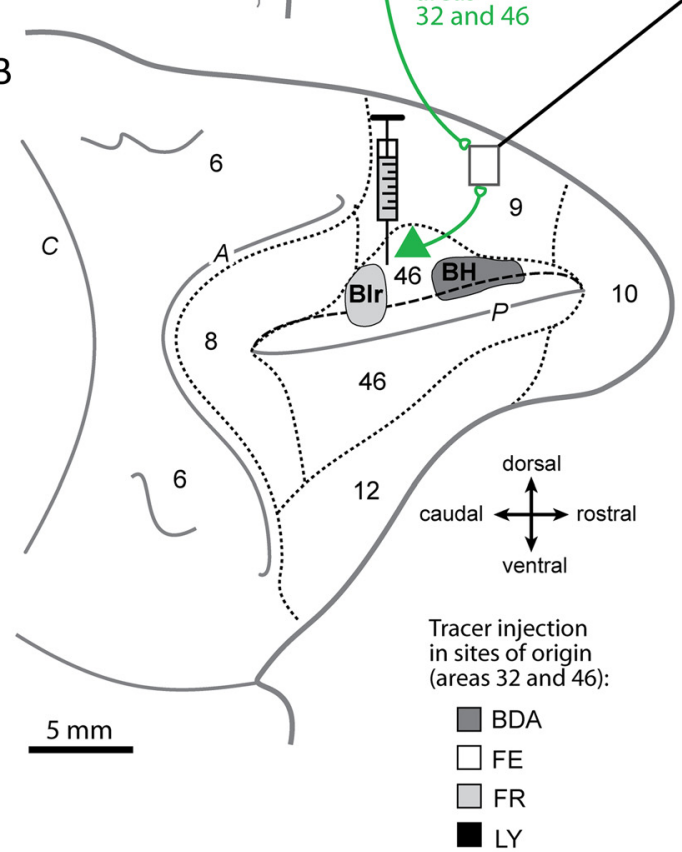

$\mathrm{F}$

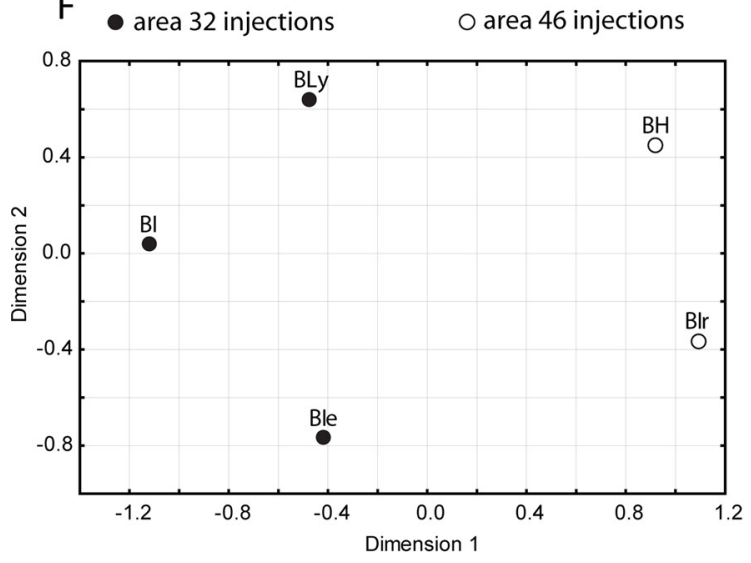

\section{Prefrontal pathway interaction} with $\mathrm{m} 2$ receptros

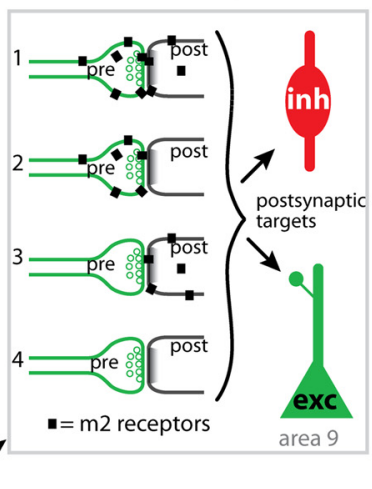

D
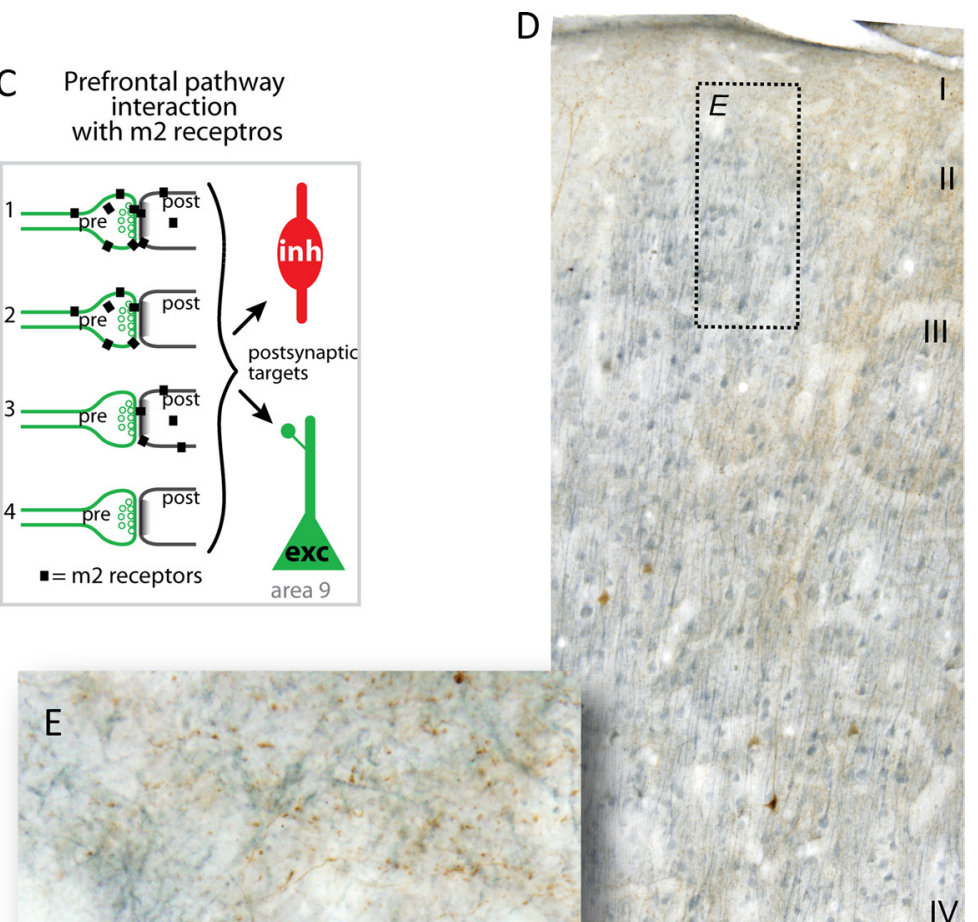

IV

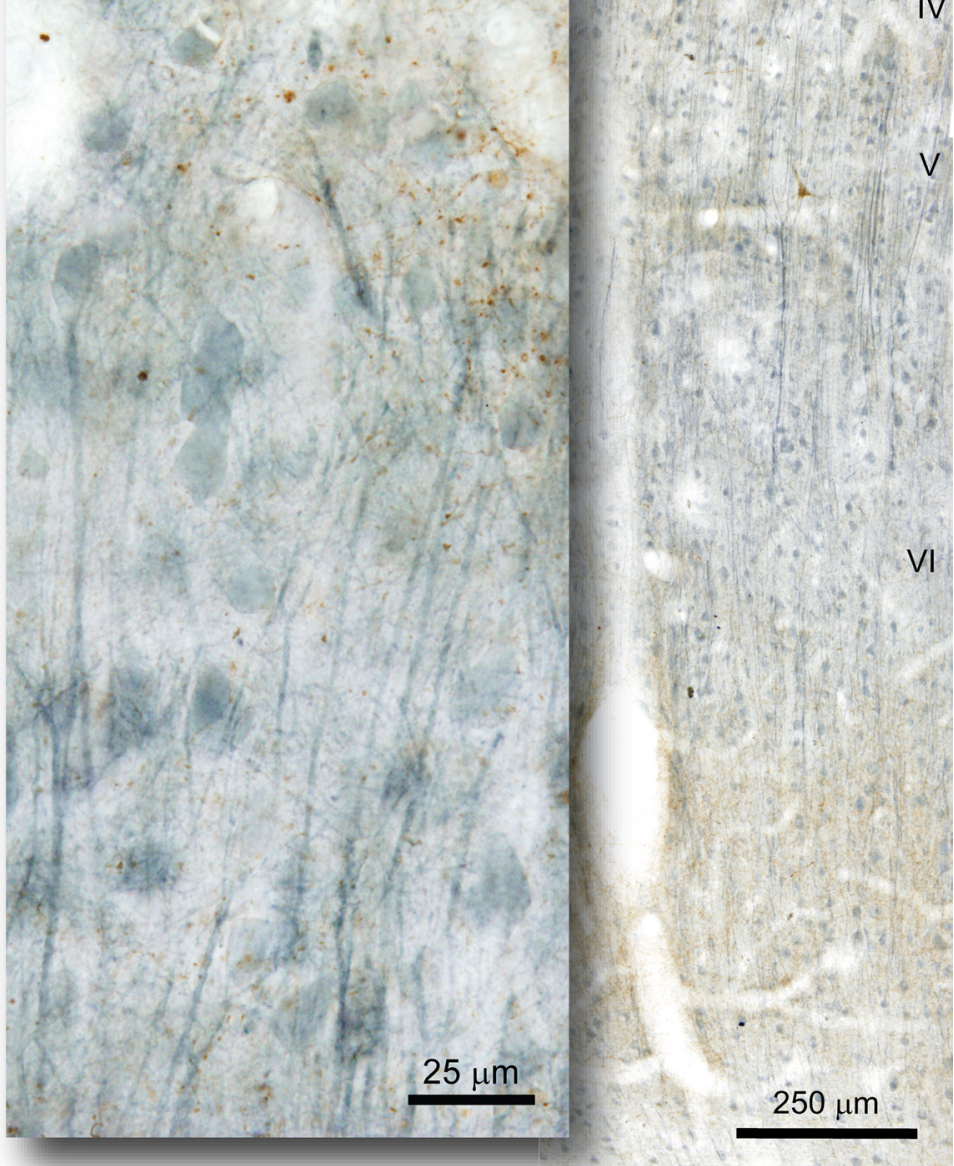

Figure 1. Labeling cholinergic $m 2$ receptors on $A C C$ and DLPFC pathways. $A, B$, Axon terminals in DLPFC area 9 were labeled with neural tracers in $A C C$ area 32 (cases $B I, B l e$, and BLy) shown on the medial surface of the rhesus monkey brain $(\boldsymbol{A})$, and in DLPFC area 46 (cases BIr and BH) on the lateral surface (long dashes depict the upper bank of the principal sulcus) ( $\boldsymbol{B}$ ). The inset in $\boldsymbol{B}$ shows the location of sites examined in area 9. Short dashes mark areal boundaries. $A$, Arcuate sulcus; $C$, central sulcus; $(g$, cingulate sulcus; $P$, principal sulcus; Ro, rostral sulcus. $C$, $S$ Chematic of the possible relationships of $\mathrm{m} 2$ receptors (black squares) with labeled axon terminals from areas 32 and 46 (pre, green) and their postsynaptic targets (post, black) that can be either excitatory (exc) or inhibitory (inh): $1, \mathrm{~m} 2$ on both presynaptic and postsynaptic sites; $2, \mathrm{~m} 2$ on presynaptic boutons only; $3, \mathrm{~m} 2$ on postsynaptic sites only; and $\mathbf{4}$, no $\mathrm{m} 2$ interaction. D, Photomicrograph of a coronal section through DLPFC area 9 double labeled for BDA axon terminals from ACC area 32 (brown) and $\mathrm{m} 2$ cholinergic receptors (blue). $\boldsymbol{E}$, Inset in $\boldsymbol{D}$ at higher magnification. Laminar labels are placed at the top of each cortical layer. $\boldsymbol{F}$, NMDS plot shows the relative clustering of cases with distinct tracer injections in ACC area 32 or DLPFC area 46, as listed in $\boldsymbol{A}$ and $\boldsymbol{B}$. (Figure legend continues.) 
processed for $\mathrm{DAB}$ to visualize the tracers (as above). The sections were fixed in $6 \%$ glutaraldehyde with $2 \%$ paraformaldehyde using a variable wattage microwave $\left(150 \mathrm{~W}\right.$ at $20^{\circ} \mathrm{C}, 3-5 \times 2 \mathrm{~min}$; Ted Pella) until sample temperature reached $>30^{\circ} \mathrm{C}$. Small pieces of tissue with label were cut, rinsed thoroughly in $\mathrm{PB}$, postfixed in osmium, dehydrated in increasing concentrations of ethanol (50-100\%), stained with $1 \%$ uranyl acetate (EM Sciences), infiltrated with propylene oxide, and flat embedded in Araldite resin (Earnest F. Fullam), as described previously (Medalla et al., 2007).

Labeling pattern of $\mathrm{m} 2$ receptors was similar across all counterbalancing methods using matched tissue sections processed with fluorescent probes, DAB, SG substrate, and silver-enhanced gold for bright-field, confocal, and electron microscopy. In some EM tissue sections using the GE Healthcare reagents, the order of precipitation methods was reversed, and the results were consistent. In control experiments, in which primary antibodies were omitted and the $\mathrm{AB}$ blocking kit was used before $\mathrm{AB}$ binding, no immunoreactivity was observed.

\section{Data analyses}

Mapping double-labeled boutons at the confocal microscope. To estimate the population of tracer-labeled boutons colocalized with $\mathrm{m} 2$ receptors, we used a confocal laser-scanning microscope (Olympus Fluoview; Olympus America) to image green (argon laser) and red (krypton laser) immunofluorescence label at high magnification $(1000 \times$ oil). Channel bleed-through was checked by scanning red and green channels separately at levels of suspected colocalization. Stacks of images were captured at $0.5 \mu \mathrm{m} z$-intervals in one to two random sites within a region of anterograde labeling in layers I and II-IIIa. Three-dimensional deconvolution was applied to image stacks using Autodeblur (Media Cybernetics) to eliminate the inevitable fluorescent signal halo. Double-labeled boutons were assessed by manually searching through each confocal stack of images for boutons labeled in both red and green channels. Counts were cross-validated by using the colocalization finder in NIH ImageJ (version 1.32j for Windows) that automatically detects the overlap of red and green labeling at a set threshold. The results from the two methods were nearly identical. Tracer-labeled boutons with or without $\mathrm{m} 2$ receptor label were counted exhaustively in each stack $(32 \rightarrow 9, n=9743$ total boutons from two injection sites; $46 \rightarrow 9, n=9339$ total boutons from two injection sites).

Mapping labeled synapses using serial EM. We mapped synapses formed by prefrontal axons at the EM as described previously (Medalla et al., 2007). We first identified two to three coronal sections with the densest anterograde label through area 9 based on bright-field maps of the labeling pattern, as described previously (Medalla and Barbas, 2009, 2010). We then processed sections from matched levels in adjacent series for immunohistochemistry (as described above), which included the entire DLPFC from the dorsal bank of the principal sulcus to dorsomedial area 9. We then cut and processed for EM the tissue segments with label and flat embedded them in resin (as described above). For each case (injection site), we cut two 300- $\mu \mathrm{m}$-wide cortical columns of dense anterograde label from layers I-IIIa of dorsal area 9, extending $\sim 700 \mu \mathrm{m}$ from the pial surface, from the aclar-embedded segments, which were then reembedded in araldite blocks for ultrasectioning. Using an ultramicrotome (Ultracut; Leica), the blocks were trimmed with a diamond trim tool and then cut into serial ultrathin sections $(50 \mathrm{~nm})$ with a diamond knife (Diatome). Serial sections were collected on single-slot pioloform-coated grids and examined at 60 or $80 \mathrm{kV}$ with a transmission EM (100CX; JEOL).

$\leftarrow$

(Figure legend continued.) NMDS analysis was used using Pearson's correlation based on targetand site-specific $\mathrm{m} 2$ receptor distribution (in layers I, II-IIIla, and pooled I-IIIa) on tracer-labeled pathways in DLPFC area 9. Tracer injections within the same architechtonic area were highly correlated (Pearson's $r=0.74-0.88, p<0.05$ ), more proximal and thus more similar to each other in terms of $\mathrm{m} 2$ distribution, than injections in a different area regardless of type of dye used. Cases with tracer injections in different architechtonic areas were dissimilar (area 32, filled circles vs area 46 , open circles) as seen by the greater distance between data points in the NMDS plots and their lower correlation coefficients $(r=0.06-0.57$; alienation coefficient $<0.0001$ for this clustering scheme).
Boutons labeled with tracer from layers I and II-IIIa were identified and analyzed separately ( $32 \rightarrow$, layer I, $n=6$ and layer II-IIIa, $n=6$ sites from three cases; $46 \rightarrow 9$, layer I, $n=4$ and layer II-IIIa, $n=4$ sites from two cases). In the two pathways examined, boutons were sampled from a comparable volume of sites from each layer for each injection site and in proportion to the depth of the layers. The average tissue block face area was $195 \times 278 \mu \mathrm{m}$ for layer I and $506 \times 280 \mu \mathrm{m}$ for layers II-IIIa. The average total volume sampled for each injection site was $\sim 6.4 \times 10^{5}$ $\mu \mathrm{m}^{3}$ for layer I and $\sim 1.3 \times 10^{6} \mu \mathrm{m}^{3}$ for layers II-IIIa. Boutons labeled with tracer and their postsynaptic elements were identified and photographed at $6600 \times$ or $10,000 \times$ using a film camera with negatives scanned at 1000 or 2000 dpi (Epson Perfection 4990 Photo Scanner; Epson America) or at $26,000 \times$ or $50,000 \times$ using a digital camera (Gatan Digital Micrograph).

Characterization of synaptic features was based on classic criteria (Peters et al., 1991). Systematic and exhaustive sampling of labeled boutons was conducted from 10-100 serial sections from each piece of tissue, which yielded an adequate sample of labeled boutons per injection site ( $32 \rightarrow 9, n=352$ total boutons from three injection sites; $46 \rightarrow 9, n=108$ total boutons from two injection sites) for either $2 \mathrm{D}$ or $3 \mathrm{D}$ analysis, as described previously (Medalla et al., 2007; Medalla and Barbas, 2009). As shown in the bright-field analysis of label of the entire pathway system (Medalla and Barbas, 2010), anterograde labeling from area 46 was less dense than from area 32, resulting in a lower yield of labeled boutons sampled exhaustively from each site within area 9.

One block from layers II-IIIa of each case was used for 3D reconstruction of labeled boutons and postsynaptic sites identified exhaustively in $\sim 80-100$ serial sections. Each bouton was followed and photographed throughout adjacent serial sections and reconstructed in 3D using the open-source program Reconstruct [www.bu.edu/neural (Fiala, 2005)]. We estimated the thickness of sections using the method of cylindrical diameters (Fiala and Harris, 2001a). We traced object contours of boutons and postsynaptic elements manually section by section and marked the $\mathrm{m} 2$ positive $\left(\mathrm{m} 2^{+}\right)$goldlabeled sites in the cytoplasm and membrane. We generated a 3D model and rendered $\mathrm{m}^{+}{ }^{+}$sites as 40 -nm-wide spheres to visualize receptor localization. Volume and surface area of presynaptic and postsynaptic elements were calculated. The 3D model was imported into 3D Studio Max (version 3; Autodesk) for additional rendering.

The rest of the blocks were used only for stereologic sampling and identification of labeled boutons and postsynaptic sites in shorter series of 10-50 sections. We sampled and photographed exhaustively all labeled boutons in either every section or every 10 adjacent sections (for longer series) at intervals of $1 \mu \mathrm{m}$ (skipping $\sim 20$ sections) to yield a proportional set of data points from each pathway.

Analysis of $\mathrm{m}^{+}$label and background levels in the neuropil. Because silver-enhanced gold labeling of receptors can produce variable levels of signal-to-noise, we used several measures to identify labeled structures. First, we sampled at consistent depths in each tissue block, avoiding the first 1-2 $\mu \mathrm{m}$ of the block surface at which background is high. Second, we set a background threshold for each piece of tissue, according to previous criteria (Muly et al., 2009). We set a minimum diameter for silverenhanced gold that was considered as positive label $(>15-20 \mathrm{~nm}$, depending on the kits used). We counted the total number of particles less than the size threshold in one in every five sections of each series and set as the background level the estimated total volume of small particles (number of particles $\times$ spherical volume of a single particle $15-20 \mathrm{~nm}$ in diameter) per volume of tissue sampled. To include a structure as $\mathrm{m} 2^{+}$, it should have at least two distinct sites of enhanced gold labeling (>15-20 nm) across serial sections, and the volume of gold particles per volume structure should be at least five times more than the background level. Third, we sampled two sites through layers I-IIIa from each case to account for possible effects of uneven tissue fixation and antibody penetration. Four blocks had lower absolute density of $\mathrm{m} 2{ }^{+}$synapses compared with the rest, which were within $<10 \%$ SE. Even in blocks with low signal, the relative distribution of $\mathrm{m} 2$ label was consistent.

To determine whether the two pathways terminate within distinct microenvironments, we quantified the distribution of $\mathrm{m} 2$ receptors in synapses found in the neuropil surrounding tracer-labeled boutons. This method served as an additional control for the overall specificity of $\mathrm{m} 2$ 


\section{A 32 to 9}

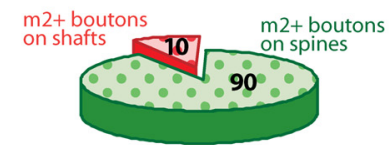

a1 Presynapticm2

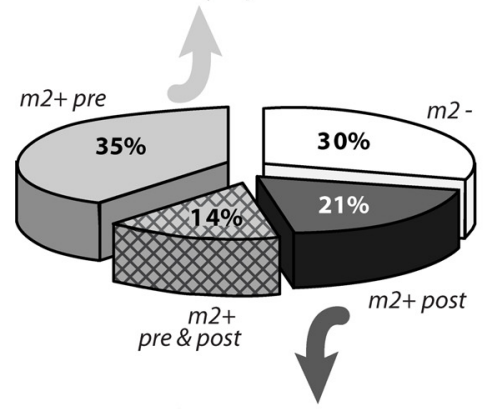

a2 Postsynapticm2 $\mathrm{m} 2+$ shafts $\mathrm{m} 2+$ spines

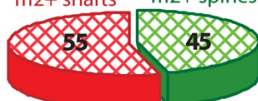

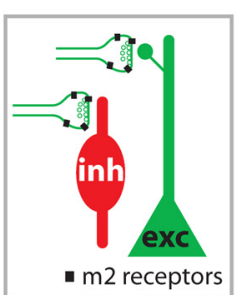

\section{B 46 to 9}

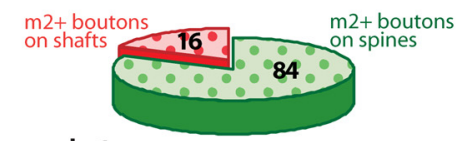

b1 Presynapticm2

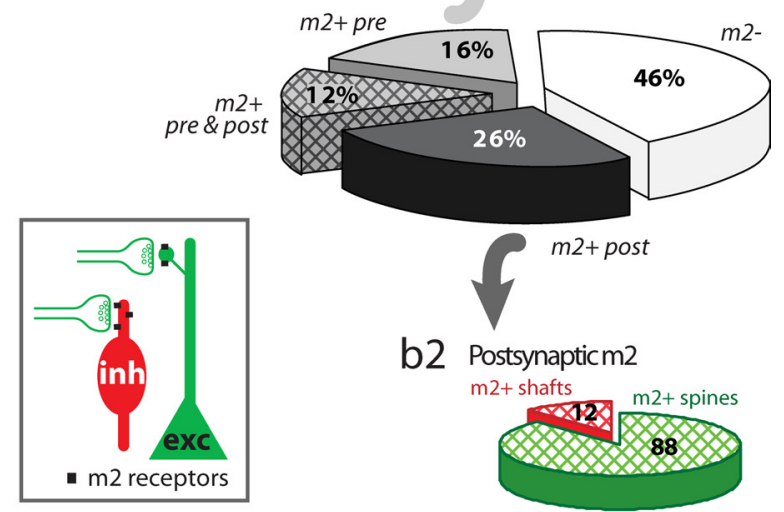

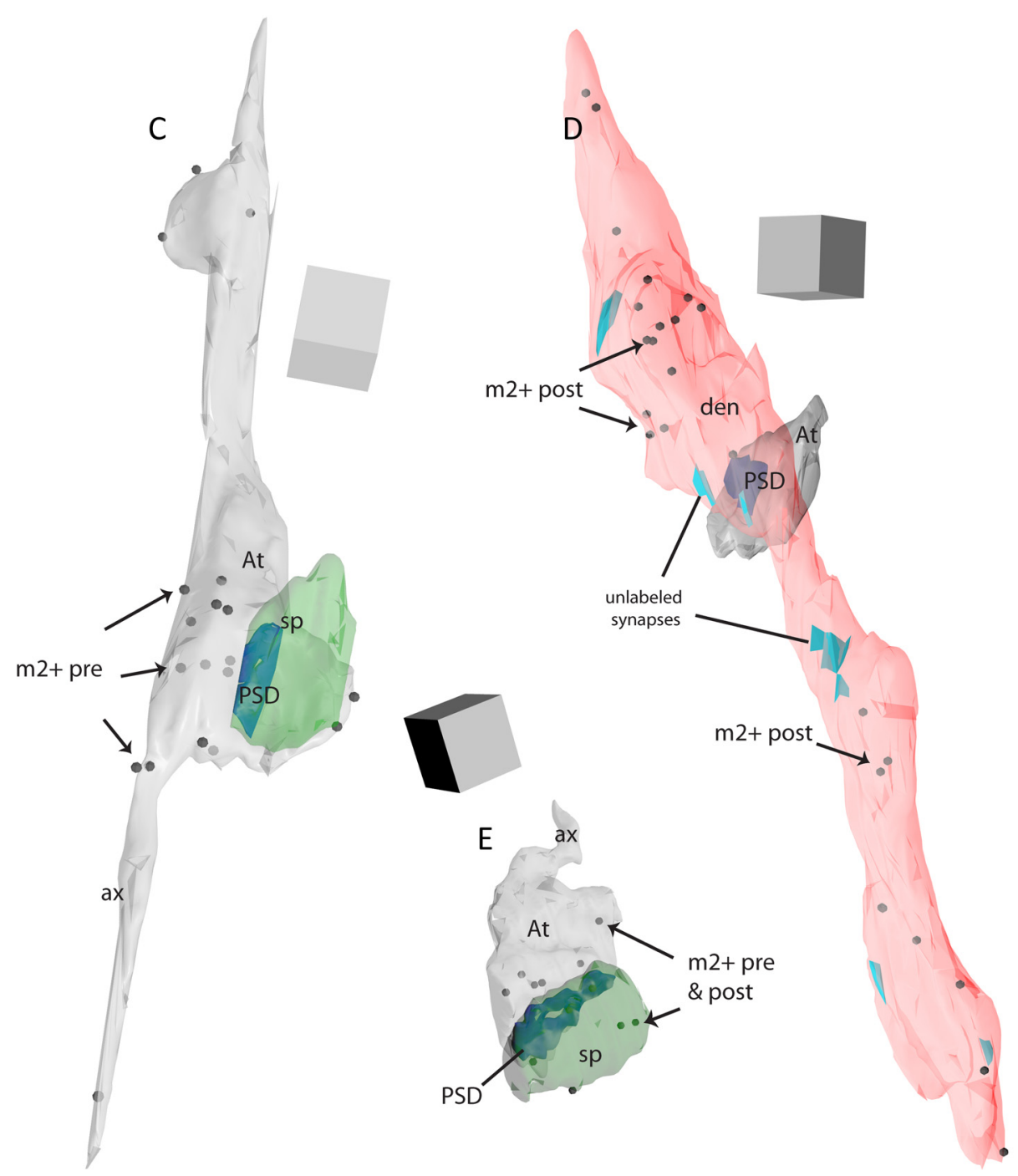

Figure 2. Distribution of 2 2 receptors on synapses formed by ACC (area 32) and DLPFC (area 46) pathways to DLPFC area 9. $\boldsymbol{A}, \boldsymbol{B}$, The center piecharts show the proportion of synapses formed by boutons from ACC area 32 to DLPFC area $9(\boldsymbol{A})$ and DLPFC area 46 to DLPFC area $9(\boldsymbol{B})$ with $\mathrm{m} 2$ receptors at presynaptic ( $\mathrm{m} 2{ }^{+}$pre, light gray) or postsynaptic sites ( $\mathrm{m} 2{ }^{+}$post, dark gray) only, at both sites $\left(\mathrm{m} 2{ }^{+}\right.$pre \& post, crosshatch), or at neither site ( $\mathrm{m} 2$ negative, $\mathrm{m} 2^{-}$, white). Top pie charts $(\boldsymbol{a} \mathbf{1}, \boldsymbol{b} 1)$ show synapses with presynaptic 2 on boutons ( $\mathrm{m} 2{ }^{+}$boutons) targeting spines (green) or dendritic (Figurelegend continues.) 
receptor staining. Using Reconstruct, we used stereologic counting of asymmetric synapses with or without $\mathrm{m} 2$ gold label in the neuropil as described previously (Fiala and Harris, 2001b; Medalla and Barbas, 2009, 2010). In each termination site of 10-40 serial sections, labeled boutons were photographed at the center of the frame and synapses around it were exhaustively counted. For each synapse identified, we tabulated the type (asymmetric or symmetric), postsynaptic target (spine or dendritic shaft), and $\mathrm{m} 2$ receptor localization (presynaptic, postsynaptic, both, or neither sites). We sampled the neuropil surrounding a random set of labeled boutons to yield a comparable volume of tissue sampled in layers II-IIIa per pathway ( $n=\sim 362$ average number of synapses; $\sim 460 \mu \mathrm{m}^{3}$ average volume of neuropil sampled per pathway, from two injection sites for each pathway).

Statistical analyses. We tabulated the frequency of presynaptic and postsynaptic $\mathrm{m} 2$ receptors on synapses formed by tracer-labeled boutons and normalized the data as a proportion of the total number of synapses formed by all labeled boutons in each layer per case (injection site). The subpopulations of spines and dendritic shafts targeted by synapses with $\mathrm{m} 2{ }^{+}$receptors were expressed as a proportion of either the total number of synapses formed by tracer-labeled boutons or the total number of $\mathrm{m} 2{ }^{+}$presynaptic or postsynaptic elements.

We used nonmetric multidimensional scaling (NMDS) analysis to consider simultaneously all relevant parameters to assess similarities across cases and to visualize potential variability across injection sites. The parameters included overall and laminar target-specific presynaptic and postsynaptic $\mathrm{m} 2$ receptor distribution on prefrontal pathways: total percentage presynaptic $\mathrm{m}^{+}$; percentage $\mathrm{m} 2^{+}$boutons on spines or dendrites; total percentage postsynaptic $\mathrm{m} 2$; and percentage postsynaptic $\mathrm{m}^{+}$spines and dendrites in layers I, II-IIIa, and the overall population in I-IIIa. NMDS analysis was conducted in Statistica (version 7 for Windows; Statsoft), using squared (dis)similarity matrices derived from $\mathrm{m} 2$ distribution profiles by Pearson's correlation as described previously (Dombrowski et al., 2001; Medalla and Barbas, 2006). NMDS considers all parameters within the multidimensional scale, and their relationship can be plotted as points in two or three dimensions. The relative proximity of the points in the NMDS scale represents their similarity. We ran the analysis using parameters from layers I, II-IIIa, and the overall population (in I-IIIa) and cross-validated by re-running the analysis with one set of parameters removed for each run. All runs produced the same NMDS plot and clustering scheme ( $p<0.05$ for all Pearson's $r$; alienation coefficient $<0.0001$ for all clustering schemes).

Data sets from each layer and pathway $(32 \rightarrow 9$, layers I and II-IIIa from three injection sites; $46 \rightarrow 9$, layers I and II-IIIa from two injection sites) were compared using one-way and multifactorial (main-effects) ANOVA to test the effects of pathway origin and layer for each variable measured, with significance level set at $p<0.05$. In all comparisons, there were no significant differences between layers I and II-IIIa, so the data were pooled. Measurements were averaged across cases and reported as mean \pm SD or SEM (confocal, $n=2$ cases for each pathway; EM, $n=3$ cases for $32 \rightarrow 9$ and $n=2$ cases for $46 \rightarrow 9$ ) and graphed in Excel or using SigmaPlot (version 7 for Windows; SPSS).

\section{$\leftarrow$}

(Figure legend continued.) shafts (red). Bottom pie charts $(\mathbf{a} \mathbf{2}, \mathbf{b 2})$ show synapses with postsynaptic 2 on spines ( $\mathrm{m}{ }^{+}$spines) or shafts ( $\mathrm{m} 2^{+}$shafts). Insets show schematic of presynaptic (top) and postsynaptic (bottom) localization of $\mathrm{m} 2$ receptors on pathway synapses with spines of excitatory (exc, green) or dendritic shafts of inhibitory (inh, red) neurons. C-E, 3D reconstructions from serial EM images of tracer-labeled boutons and their synapses (postsynaptic density, PSD) and postsynaptic targets in layers II-IIla of area 9 show the localization of $\mathrm{m} 2$ receptors. $C$, Bouton from area 32 (At) with presynaptic $\mathrm{m} 2$ receptors ( $\mathrm{m} 2^{+}$pre, black dots) forming a synapse (PSD, blue) with a spine (sp, green). D, Bouton from area 32 (At) forming a synapse (PSD) with a smooth dendrite of an inhibitory neuron (den, pink) with postsynaptic $m 2$ receptors ( $\mathrm{m2}^{+}$post). Note the presence of other synapses (not tracer-labeled, light blue) on the dendritic shaft, characteristic of the placement of synapses on dendrites of inhibitory neurons in the cortex. $\boldsymbol{E}$, Bouton from area 46 (At) with presynaptic $\mathrm{m} 2$ receptors forming a synapse (PSD) with a spine (sp) with postsynaptic $\mathrm{m} 2$ receptors (m2+ pre and post). Scale cube, $0.5 \mu \mathrm{m}^{3}$.

\section{Results}

\section{Overview of $\mathrm{m} 2$ labeling in DLPFC area 9 and relationship to pathways}

We first studied the overall distribution of cholinergic $\mathrm{m} 2$ receptors in DLPFC area 9. Labeling of $\mathrm{m} 2$ receptors on thin coronal sections $(50 \mu \mathrm{m})$ revealed a band of strong label in the upper layers (I-IIIa) and in the deep layers (V-VI) of area 9 (Fig. 1D). Label for $\mathrm{m} 2$ was found in processes and, to a lesser extent, cell bodies of pyramidal and nonpyramidal neurons (Fig. $1 E$ ), consistent with previous studies in the cortex (Lidow et al., 1989; Mrzljak et al., 1993; Mrzljak et al., 1998; Erisir et al., 2001).

We then studied the interaction of $\mathrm{m} 2$ receptors in two distinct prefrontal pathways to area 9. The pathways, which were labeled with neural tracers, originated in either ACC area 32 or DLPFC area 46 and terminated in DLPFC area 9 (Fig. $1 A, B$ ). The injection sites in dorsal area 46 occupied a caudal part (case BIr) and a more rostral site within the same architectonic area (case $\mathrm{BH}$; Fig. $1 \mathrm{~B}$ ). Injection sites in area 32 included two distinct tracers in the same animal, found in the central part and spanning through the entire dorsoventral extent of the area (cases BI and BIe; Fig. $1 A$ ). A third injection in area 32 (case BLy) occupied a relatively more dorsal and caudal sector (Fig. $1 A$ ). There was thus some variability in the topography and overall size of the injection sites. Nevertheless, the distribution of labeled fibers in dorsolateral area 9 was consistent among cases in each pathway, as found in previous quantitative analysis of the same pathways (Medalla and Barbas, 2010). In other studies, we found no evidence of hemispheric differences in the pattern or density of labeling in corticocortical or corticothalamic pathways (Germuska et al., 2006; Zikopoulos and Barbas, 2006, 2012; Medalla et al., 2007; Medalla and Barbas, 2010) or differences in labeling of pathways based on sex (Germuska et al., 2006; Zikopoulos and Barbas, 2006, 2012; Medalla et al., 2007). However, based on the cases in this study, we cannot rule out potential contributions of hemisphere or sex to the pattern of labeling.

The overall pattern and density of labeled boutons differed in the two pathways to area 9. Axons from area 32 terminated in wide columns covering a large extent of area 9, whereas axons from area 46 terminated in restricted patches in area 9. The two pathways to area 9 also differed in laminar termination pattern, with area 32 boutons found mostly in the upper layers, and area 46 boutons distributed evenly across the layers in a columnar pattern. We investigated layers I-IIIa of area 9, in which axons from both pathways terminated robustly.

We found that, in layers I-IIIa of area 9, $\mathrm{m} 2$ receptors were intermingled with the tracer-labeled axon fibers and terminals from areas 32 and 46 (Fig. $1 D, E$ ). As shown in Figure $1 C$, the tracer-labeled axons, which are excitatory (glutamatergic), could form asymmetric synapses on two postsynaptic targets: spines of presumed excitatory neurons (Fig. 1C, exc, green) or shafts of presumed inhibitory neurons (Fig. 1C, inh red). Furthermore, for any given synapse formed by a labeled bouton, $\mathrm{m} 2$ receptors could be present at both the presynaptic and postsynaptic sites (Fig. 1C1), only at the presynaptic site (Fig. 1C2), only at the postsynaptic site (Fig. 1C3), or at neither site (Fig. 1C4), totaling eight possible combinations. We computed the prevalence of each possible outcome at the EM in layers I and II-IIIa of each case. NMDS analysis using Pearson's correlation based on $\mathrm{m} 2$ receptor distribution profiles by layer (I and II-IIIa) and in the overall population (I-IIIa) showed the relative similarity (proximity) of injection sites within the same architectonic area (Fig. $1 F)$. Area 32 cases (injection sites in cases BI, BIe, and BLy) re- 

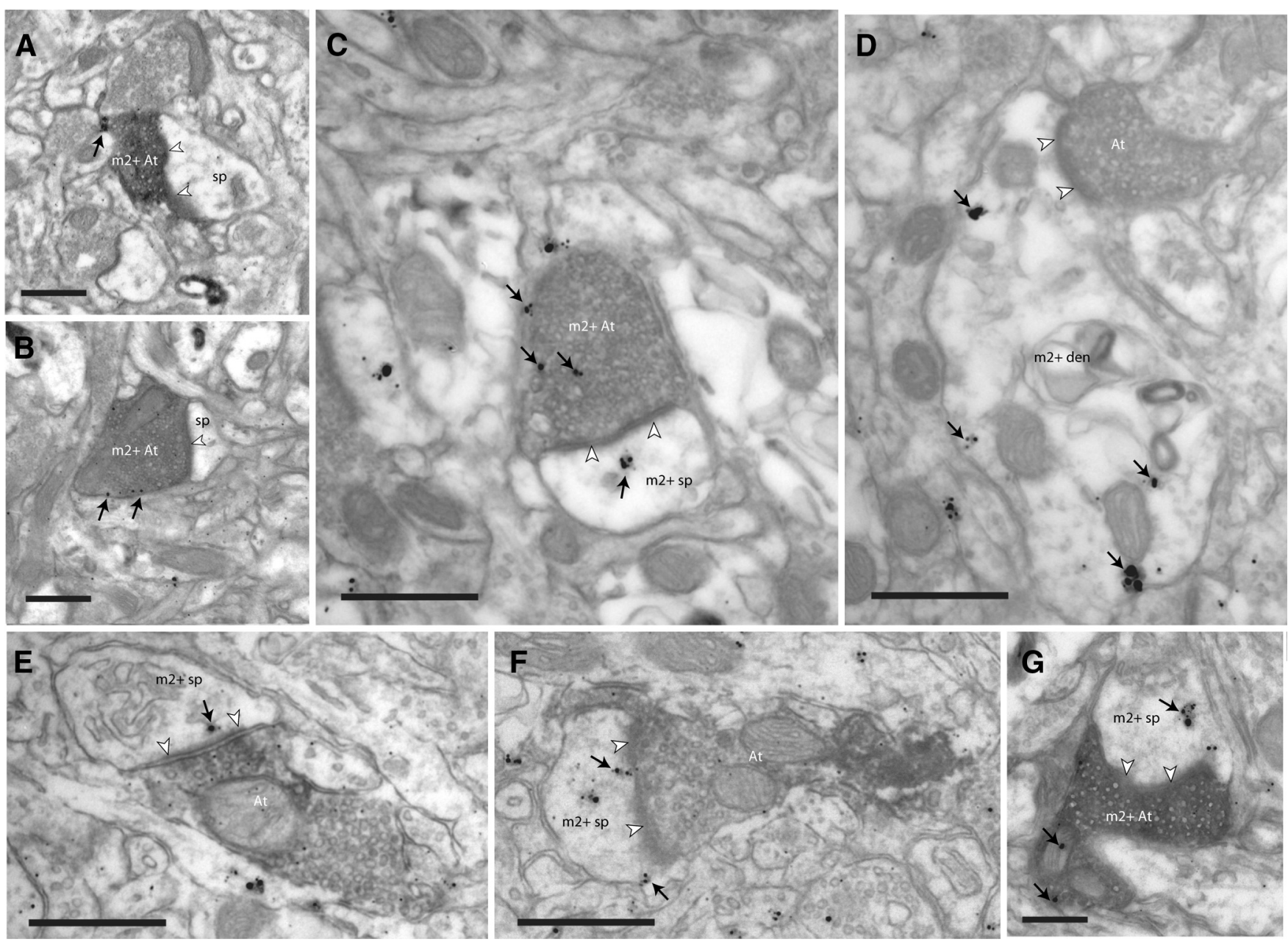

Figure 3. Localization of $\mathrm{m} 2$ receptors in synapses of tracer-labeled pathways. EM photomicrographs show tracer-labeled axon terminals (At) and $\mathrm{m} 2$ receptors (silver-enhanced gold particles; black arrows) near the synapse (white arrowheads). $A, B$, Presynaptic $\mathrm{m} 2$ receptors on the membranes of boutons from ACC (area 32) labeled with BDA tracer ( $\mathrm{m} 2^{+} \mathrm{At}$ ) innervating spines (sp) in area 9. C, Presynaptic $\mathrm{m} 2$ receptors on the membrane and cytoplasm of a tracer-labeled bouton from ACC (FE), which forms a synapse with a spine with postsynaptic $\mathrm{m} 2$ receptors ( $\mathrm{m} 2{ }^{+} \mathrm{sp}$ ) in the cytoplasm (black arrows). $\boldsymbol{D}$, Postsynaptic $\mathrm{m} 2$ receptors on the membrane and cytoplasm of a dendrite $\left(\mathrm{m} 2^{+}\right.$den) innervated by a tracer-labeled bouton from $\mathrm{ACC}$. $\boldsymbol{E}, \boldsymbol{F}, \mathbf{B}$ Boutons from DLPFC area 46 labeled with tracer (FR), each innervating a spine with postsynaptic $\mathrm{m} 2$ receptors, near the postsynaptic density. G, Tracer-labeled bouton from area 46 (BDA) with presynaptic $\mathrm{m} 2$ receptors innervates a spine with postsynaptic $\mathrm{m} 2$ receptors in the cytoplasm. Scale bar, $0.5 \mu \mathrm{m}$.

sembled each other and were segregated from cases with tracer injections in area 46 (cases BH and BIr), regardless of type of dye used. Cases with tracer injection within one architectonic area showed higher within-group correlation coefficients (Pearson's $r=0.74-0.88, p<0.05$ ), whereas between-group correlation coefficients were lower $(r=0.06-0.57)$. Consistent with the NMDS analysis, multivariate comparisons of $\mathrm{m} 2$ receptor distribution profiles revealed a significant effect of pathway origin from area 32 or 46 (main-effects ANOVA, $p<0.05$ ) but no effect by layer of termination (I vs II-IIIa, $p>0.05$ ), as elaborated below.

The pathways from areas 32 and 46 formed asymmetric synapses in area 9 with spines, enriched in excitatory neurons, or aspiny/sparsely spiny dendritic shafts, characteristic of cortical inhibitory neurons $(32 \rightarrow 9,79 \%$ on spines, $21 \%$ on shafts; $46 \rightarrow$ $9,89 \%$ on spines, $11 \%$ on shafts). However, the pathway from ACC area 32 targeted more shafts of presumed inhibitory neurons in DLPFC area 9 than the pathway from DLPFC area 46. We also found a pathway-specific difference in the size of boutons and synapses, which is correlated with synaptic efficacy (Tong and Jahr, 1994; Murthy et al., 1997; Germuska et al., 2006; Zikopoulos and Barbas, 2007; for review, see Nimchinsky et al., 2002;
Bourne and Harris, 2008). Labeled boutons from area 32 and their associated synapses were relatively larger than those from area 46 , especially boutons innervating dendritic shafts of presumed inhibitory neurons (bouton volume, $\sim 0.20 \mu \mathrm{m}^{3}$ for $32 \rightarrow$ 9, $\sim 0.17 \mu \mathrm{m}^{3}$ for $46 \rightarrow 9$ ) or those that formed multiple synapses (volume, $\sim 0.39 \mu \mathrm{m}^{3}$ for $32 \rightarrow 9$ and $\sim 0.28 \mu \mathrm{m}^{3}$ for $46 \rightarrow 9$ ). These findings confirm and extend our previous studies (Medalla and Barbas, 2009, 2010).

In the population of tracer-labeled boutons that formed identifiable synapses, $\mathrm{m} 2$ receptors labeled with silver-intensified gold were found presynaptically (Figs. $2 A, B$, light gray, $C, 3 A, B$ ), postsynaptically (Figs. $2 A, B$, dark gray, $D, 3 D-F$ ), or at both sites (Figs. $2 A, B$, crosshatch, $E, 3 C, G$ ). In synapses with $\mathrm{m} 2$ labeling, most receptors were found in extrasynaptic and perisynaptic membranes (Fig. $3 A-D$ ), including a few that were near or within the presynaptic or postsynaptic membrane specializations (Fig. $3 F$ ), but some were found within the cytoplasm (Fig. $3 D, E, G$ ).

\section{Presynaptic specificity of $\mathrm{m} 2$ cholinergic receptors in pathways from areas 32 and 46 to area 9}

We then examined the incidence of presynaptic $\mathrm{m} 2$ receptors on tracer-labeled boutons ( $\mathrm{m} 2^{+}$boutons) from areas 32 and 46 , in 
which they can inhibit neurotransmitter release (for review, see Lucas-Meunier et al., 2003). At the population level using confocal microscopy, we found that a significant proportion of axon terminals in the upper layers of area 9 were double labeled for $\mathrm{m} 2$ receptors and tracers injected in areas 32 or 46 (Figs. $4 A$, 5, yellow; an average of $\sim 9500$ boutons per pathway). However, there was a higher proportion of $\mathrm{m} 2{ }^{+}$boutons in the $32 \rightarrow 9$ pathway ( $37 \pm 6 \%$ of tracer-labeled boutons) than in the $46 \rightarrow 9$ pathway $(16 \pm 9 \%$; one-way ANOVA, $p<0.05$; Fig. $4 A$ ).

Electron microscopic analysis confirmed this pathwayspecific difference, in which the effect was more pronounced because the detection threshold for $\mathrm{m} 2$ label is lower at the much higher resolution, and the postsynaptic targets are visible (an average of $\sim 230$ boutons per pathway; Figs. 3, 4B). We found that the proportion of $\mathrm{m}^{+}$boutons (synaptic and nonsynaptic) from area 32 was significantly higher than from area $46(32 \rightarrow 9$, $52 \pm 3 \% ; 46 \rightarrow 9,30 \pm 2 \%$; one-way and main effect ANOVA, $p<0.05$; Fig. $4 B$ ). The difference was specifically attributable to a significantly higher prevalence of $\mathrm{m}^{+}$boutons from area 32 innervating spines (Fig. $4 C$, black asterisks, ${ }^{\star} p<0.05$ ). In general, most $(84-90 \%) \mathrm{m} 2{ }^{+}$boutons targeted spines in both pathways (Fig. 2Aa1,Bb1). However, approximately half of the spinetargeting boutons in the $32 \rightarrow 9$ pathway had presynaptic $\mathrm{m} 2$ receptors ( $43 \pm 3 \%$ of all boutons), nearly twice as many as in the $46 \rightarrow 9$ pathway ( $28 \pm 6 \%$ of all boutons; Fig. $4 C$, black asterisks, $\left.{ }^{*} p<0.05\right)$. The opposite pattern was found for spine-targeting boutons with no presynaptic $\mathrm{m} 2$ receptors, which were significantly more prevalent in the area 46 to 9 pathway $(62 \pm 1 \%$ of all boutons) than in the pathway from area 32 to area 9 (36 $\pm 2 \%$ of all boutons; Fig. $4 C$, gray asterisks, ${ }^{\star} p<0.01$ ).

In contrast, of all the boutons that innervated dendritic shafts, the proportion with presynaptic $\mathrm{m} 2$ receptors was similar in the two pathways ( $p=0.73,4-5 \%$ of all boutons; Fig. $4 C$, on shafts, black bars). Moreover, the proportion of these shaft-targeting boutons with no presynaptic $\mathrm{m} 2$ receptors was significantly higher in the area $32 \rightarrow 9$ pathway than in the $46 \rightarrow 9$ pathway ( $16 \pm 1$ vs $4 \pm 2 \%$ of all boutons; Fig. $4 C,{ }^{\#} p<0.01$ ). The above evidence suggests that acetylcholine can act presynaptically through $\mathrm{m} 2$ receptors to inhibit the release of glutamate from boutons innervating spines more commonly in the ACC pathway to DLPFC area 9 than in the pathway linking the functionally similar DLPFC areas 46 to 9.

\section{Postsynaptic specificity of $\mathrm{m} 2$ cholinergic receptors in pathways from areas 32 and 46 to area 9}

We found that $\mathrm{m} 2$ receptors were also localized at postsynaptic sites, in which muscarinic activation has mostly depolarizing effects (for review, see Lucas-Meunier et al., 2003). The overall proportion of postsynaptic targets with $\mathrm{m} 2$ receptors was comparable in the two pathways that terminate in area $9(32 \rightarrow 9$, $30 \pm 7 \% ; 46 \rightarrow 9,35 \pm 9 \% \mathrm{~m} 2{ }^{+}$postsynaptic sites of all pathway synapses). However, the two pathways differed in the proportion of their postsynaptic targets with $\mathrm{m} 2$ receptors, which are presumed to be excitatory (synapses on spines) or inhibitory (synapses on shafts) (Fig. 6). The pathway from area 32 targeted approximately the same proportion of spines or shafts with $\mathrm{m} 2{ }^{+}$ receptors in area $9\left(55 \pm 6 \%\right.$ of all $\mathrm{m} 2{ }^{+}$targets were on shafts; Figs. $2 A a 2,6 B)$. In contrast, the pathway from area 46 targeted preferentially $\mathrm{m} 2^{+}$spines in area $9\left(88 \pm 3 \%\right.$ of all $\mathrm{m} 2^{+}$targets; Figs. $2 \mathrm{Bb} 2,6 \mathrm{~B})$. Thus, the $32 \rightarrow 9$ pathway targeted significantly more $\mathrm{m} 2{ }^{+}$dendritic shafts and concomitantly fewer $\mathrm{m} 2^{+}$spines than the $46 \rightarrow 9$ pathway ( $p<0.01$ for the ratio of $\mathrm{m} 2{ }^{+}$spines to shafts; Fig. $6 B$ ). Most postsynaptic shafts innervated by area 32
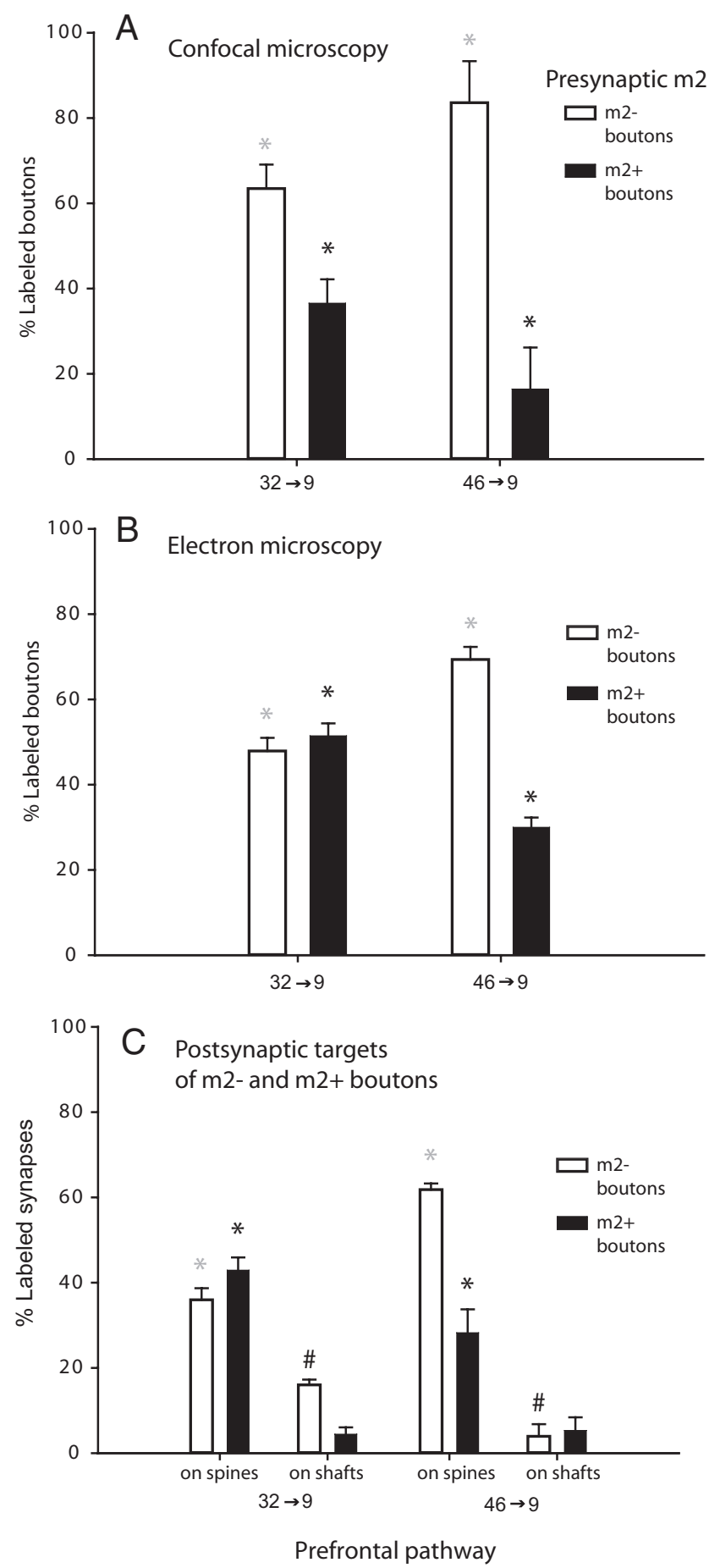

Figure 4. ACC and DLPFC pathways differed in extent of presynaptic $m 2$ receptors. Overall proportion of tracer-labeled boutons (synaptic and nonsynaptic) in layers I-IIla of DLPFC area 9 , with (black bars) or without (silhouette bars) $\mathrm{m} 2$ receptors, sampled at the confocal microscope ( $32 \rightarrow 9, n=9743$ total boutons from 2 cases; $46 \rightarrow 9, n=9339$ total boutons from 2 cases) $(A)$ and at the $\mathrm{EM}(32 \rightarrow 9 n=352$ total boutons from 3 cases; $46 \rightarrow 9, n=108$ total boutons from 2 cases) (B). Presynaptic $m 2$ receptors were significantly more prevalent in boutons from ACC area 32 than from DLPFC area $46\left({ }^{*} p<0.05\right)$. Significantly different comparisons are indicated by matching symbols above the bars in each graph. C, Postsynaptic spines and dendrites targeted by tracer-labeled boutons with or without $\mathrm{m} 2$ receptors in each pathway. There were significantly more $\mathrm{m}^{+}{ }^{+}$boutons (black asterisks, ${ }^{*} p<0.05$ ) and concomitantly fewer $\mathrm{m} 2{ }^{-}$boutons (gray asterisks, ${ }^{*} p<0.01$ ) that targeted spines in the area 32 pathway than in the area 46 pathway. In contrast, there were more $\mathrm{m}^{-}$boutons that targeted shafts in the pathway from area 32 than from area $46\left({ }^{\sharp} p<0.01\right)$. Sum of all bars from each pathway is $100 \%$. 

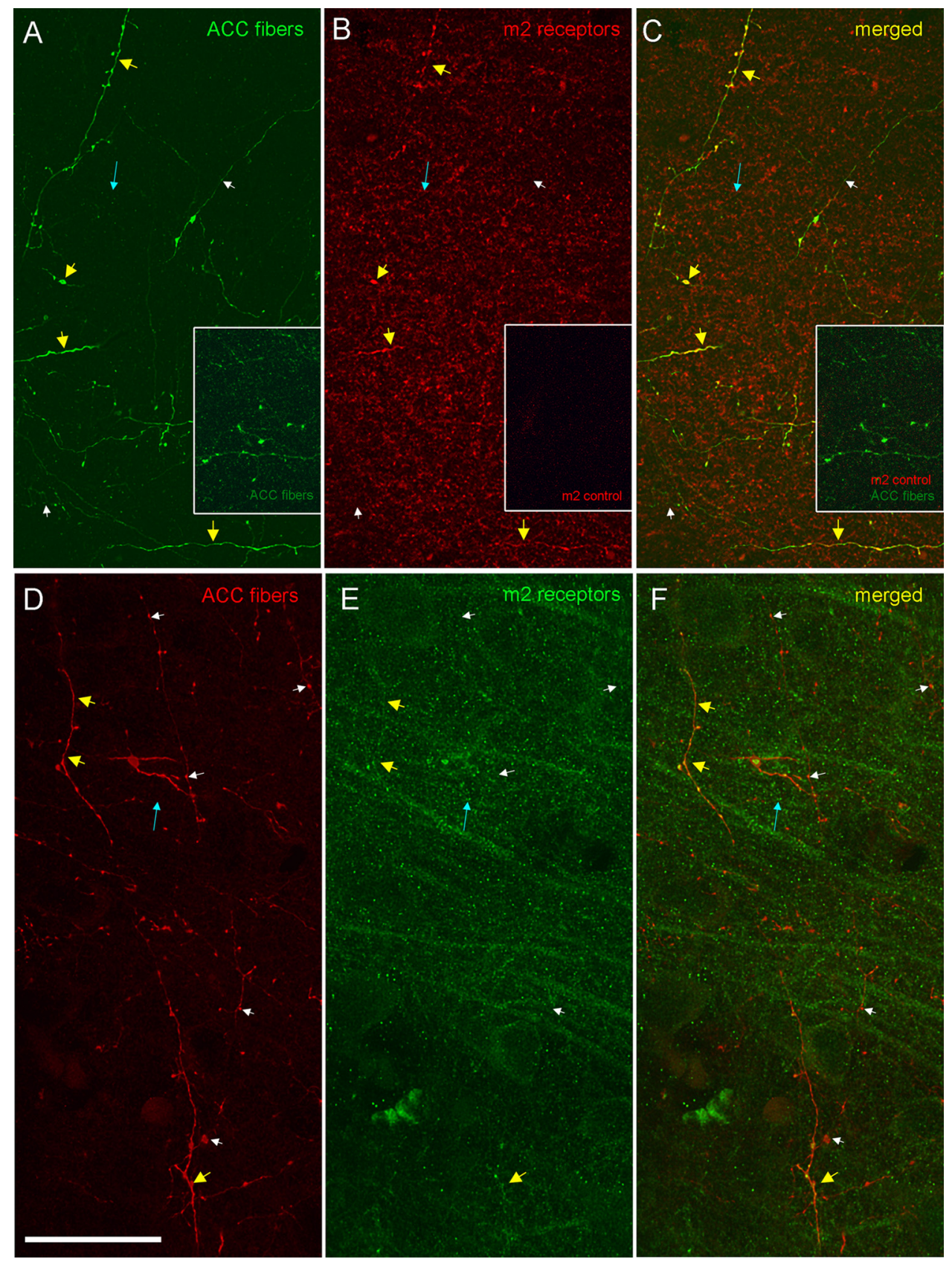

Figure 5. Colocalization of tracer-labeled fibers with $\mathrm{m} 2$ receptors in the ACC pathway. $A-C$, Confocal image stack in layer I of DLPFC area 9 shows dual immunofluorescence labeling of axon fibers from ACC area 32 (FE tracer, green channel) $(\boldsymbol{A})$ and $\mathrm{m} 2$ receptors (red channel) $(\boldsymbol{B})$. $\boldsymbol{C}$, Merged red and green channels show double-labeled fibers in yellow (yellow arrows). Some fibers were single labeled with tracer (white arrows) or $\mathrm{m} 2$ receptors only (blue arrows). Insets in $\boldsymbol{A}-\boldsymbol{C}$ show the corresponding control experiment in an adjacent section and matched site. $A$, Inset, Immunofluorescence for tracer-labeled fibers (green, FE). $\boldsymbol{B}$, Inset, Control; there was no evidence of $\mathrm{m} 2$ immunoreactivity when the primary antibody for $\mathrm{m} 2$ was omitted (red). $\boldsymbol{C}$, Inset, Merge of $\boldsymbol{A}$ and $\boldsymbol{B}$ insets. $\boldsymbol{D}-\boldsymbol{F}$, Confocal image stack in layers II-IIla of area 9 shows dual labeling of axon fibers from ACC area 32 (BDA tracer, red) (D) and $\mathrm{m} 2$ receptors (green) (E). $\boldsymbol{F}$, Merged channels show double-labeled fibers in yellow (yellow arrows). Scale bar, $25 \mu \mathrm{m}$.

were positive for $\mathrm{m} 2$ receptors ( $78 \pm 10 \%$ of all shafts targeted; $15 \pm 4 \%$ of all synapses), more than threefold higher than for the pathway from area $46(21 \pm 2 \%$ of all shafts targeted, $p<0.01$; $3 \pm 1 \%$ of all synapses; Fig. $\left.6 A,{ }^{*} p<0.05\right)$. The opposite trend was found for the incidence of $\mathrm{m} 2^{+}$spines innervated by each pathway, but the difference was not statistically significant $(p=$ 0.22 ; Fig. $6 A$ ). This evidence suggests that the potential $\mathrm{m} 2$ receptor-mediated postsynaptic effects of acetylcholine are more predominant on spines of presumed excitatory neurons innervated by area 46 but on shafts of presumed inhibitory neurons innervated by area 32 .

\section{$\mathrm{m} 2$ receptor distribution in the surrounding neuropil}

We then investigated the distribution of $\mathrm{m} 2$ receptors in synapses in the neuropil surrounding tracer-labeled boutons to determine whether the two pathways terminate in distinct microenvironments. The distribution of $\mathrm{m} 2$ receptors in the surrounding neuropil was comparable across distinct termination sites of areas 32 and 46 in area 9, with similar $\mathrm{m} 2$ localization in the cytoplasm and membranes of presynaptic axons and boutons and postsynaptic spines and dendritic shafts. In the neuropil surrounding labeled boutons from both areas 32 (Fig. 7A) and 46 (Fig. 7B), most $\mathrm{m} 2$ receptors were associated with asymmetric synapses 
( $\sim 95 \%$ of $\mathrm{m} 2^{+}$synapses), in which they were similarly localized on presynaptic and postsynaptic elements ( $\sim 26 \%$ of synapses with presynaptic $\mathrm{m} 2 ; \sim 23 \%$ with postsynaptic $\mathrm{m} 2 ; \sim 17 \%$ with both presynaptic and postsynaptic $\mathrm{m} 2$ ). Presynaptic $\mathrm{m} 2$ receptors in the neuropil were mostly found on synapses with spines (Fig. $7 A a 1, B b 1 ; \sim 90 \%$ of $\mathrm{m} 2{ }^{+}$boutons). Postsynaptic $\mathrm{m} 2$ receptors were found on spines $\left(\sim 62 \%\right.$ of $\mathrm{m}^{+}{ }^{+}$targets $)$and shafts $\left(\sim 38 \%\right.$ of $\mathrm{m}^{+}$targets; Fig. $\left.7 \mathrm{Aa} 2, \mathrm{Bb2}\right)$ in proportions similar to the pathway from area 32 to area 9 . A small proportion $(\sim 5 \%)$ of synapses with presynaptic or postsynaptic $\mathrm{m} 2$ receptors were symmetric (and presumed inhibitory), which were also similar in the neuropil surrounding labeled boutons from both pathways (data not shown).

The pattern of $\mathrm{m} 2$ receptor distribution in the surrounding neuropil also served as a control for the overall specificity of $\mathrm{m} 2$ receptor staining. The molecular specificity of the antibody has been described previously (Mrzljak et al., 1993; Levey et al., 1995), and here we found patterns of $\mathrm{m} 2$ labeling in area 9 both at the light and electron microscopes, consistent with previous findings in the cortex (Lidow et al., 1989; Mrzljak et al., 1998; Erisir et al., 2001). We found similar patterns of $\mathrm{m} 2$ labeling in tissue processed using counterbalancing methods (Figs. 1D,E, SG substrate; 5, 7G, fluorescence; 7C, $\mathrm{DAB} ; 7 E$, silver-enhanced gold). Matched sections in control experiments, in which the primary antibody was omitted, yielded no labeling when processed for bright-field microscopy (Fig. 7D,F) or for immunofluorescence (Figs. $5 A-C$, insets, $7 H$ ), indicating the specificity of the antibody.

In summary (Fig. 8), the following features distinguish the two pathways with respect to $\mathrm{m} 2$ receptor distribution: (1) boutons from ACC area 32 that formed synapses with spines have more presynaptic $m 2$ receptors than boutons from DLPFC area 46 (Fig. 8, insets, compare $1 b, 2 b$ ); and (2) area 32 boutons targeted more $\mathrm{m} 2^{+}$dendritic shafts of inhibitory neurons (Fig. 8, left inset, $1 c$ ), whereas area 46 boutons targeted more $\mathrm{m} 2{ }^{+}$spines (Fig. 8, right inset, $2 d$ ). These features collectively show prefrontal pathway specificity in $\mathrm{m} 2$ receptor localization, and in turn, suggest diversity in the associated cholinergic neuromodulatory influence.

\section{Discussion}

The robust connections between the ACC and DLPFC underlie their communication and distinct roles in cognitive tasks (Kaping et al., 2011; for review, see Barbas et al., 2002; Lee et al., 2007; Johnston and Everling, 2008; Rushworth et al., 2011). Cholinergic modulation in the two regions differs perhaps because of the denser cholinergic innervation of ACC than DLPFC (Mesulam et al., 1992; Ghashghaei and Barbas, 2001). This anatomic inequality is accentuated during REM sleep, when cortical activity is under the predominant influence of the cholinergic system while other neuromodulatory systems remain dormant (for review, see Muzur et al., 2002). During REM sleep, the ACC is strongly activated but DLPFC is essentially silent (Maquet et al., 1996; Braun et al., 1997; Tian et al., 2002, 2006), despite a strong excitatory projection from ACC that targets primarily excitatory postsynaptic sites in DLPFC (Medalla and Barbas, 2010). Our findings suggest that this paradox may be explained by the synaptic specificity of $\mathrm{m} 2$ cholinergic receptors in the ACC pathway to DLPFC9 via dual mechanisms at presynaptic and postsynaptic sites.

At the presynaptic level, we found a higher prevalence of $\mathrm{m} 2$ receptors on boutons from ACC axons than in the pathway from area 46 to 9, two DLPFC areas that have common and likely synergistic roles in working memory (for review, see Petrides,
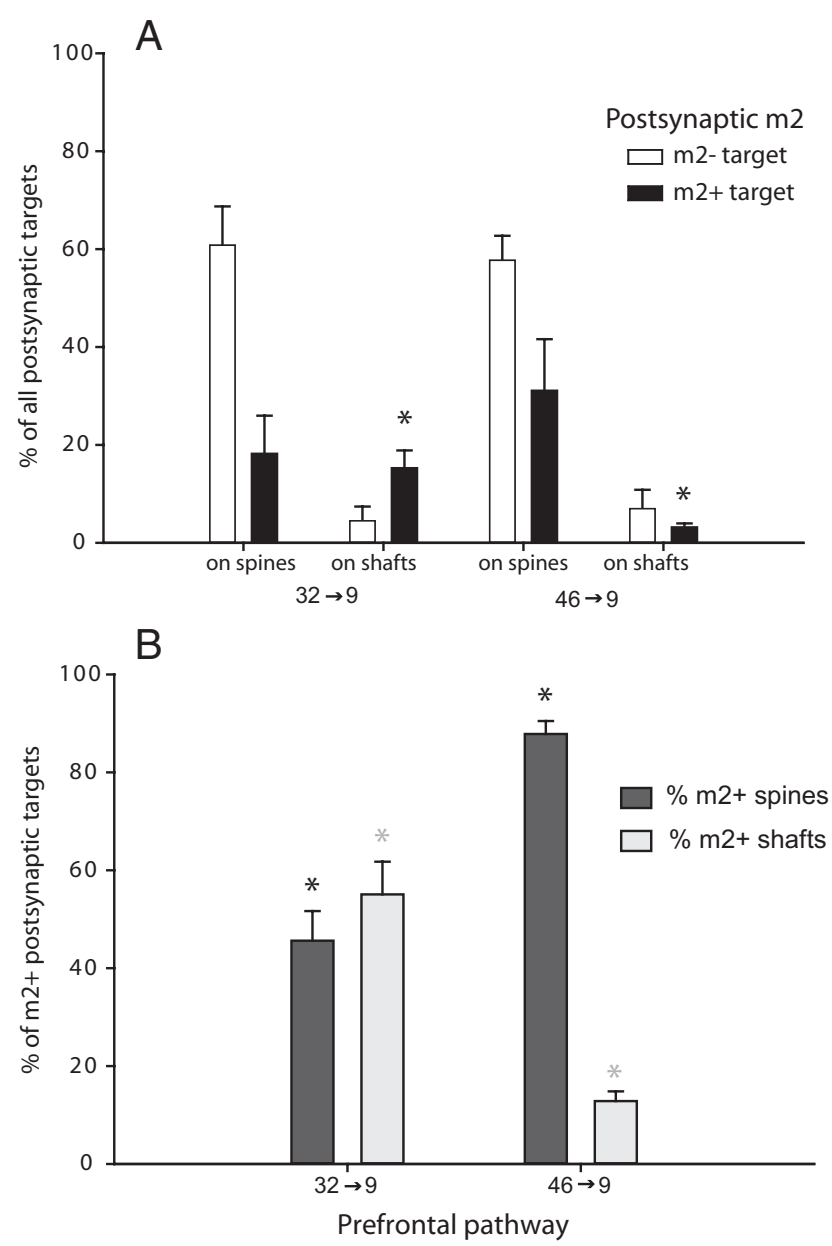

Figure 6. $A C C$ and DLPFC pathways differed in their postsynaptic targets with $\mathrm{m} 2$ receptors $A$, The distribution of postsynaptic spines and dendrites with (black bars) or without (silhouette bars) $\mathrm{m} 2$ receptors targeted by pathways from ACC area 32 and DLPFC area 46 in layers I-IIlla of DLPFC area 9 obtained at the EM. Axons from ACC area 32 targeted more $\mathrm{m}^{+}{ }^{+}$shafts than area 46 in area $9\left({ }^{*} p<0.05\right)$. Significantly different comparisons are indicated by matching symbols above the bars in each graph. $\boldsymbol{B}$, The relative distribution of $\mathrm{m}^{+}$spines and $\mathrm{m}^{+}{ }^{+}$dendrites normalized to the total $\mathrm{m}^{+}$postsynaptic targets in each pathway. The ratio of $\mathrm{m}^{+}{ }^{+}$spines: shafts significantly differed in the two pathways $\left({ }^{*} p<0.01\right)$. Sum of all bars from each pathway is $100 \%$.

2000; Barbas et al., 2002). The significance of this synaptic specialization in the ACC pathway is based on physiologic findings indicating that activation of presynaptic cholinergic receptors may enhance or inhibit release of neurotransmitter from nerve terminals depending on receptor subtype (for review, see Levey, 1996; Lucas-Meunier et al., 2003; Hasselmo and Giocomo, 2006). Presynaptic suppression is primarily mediated by muscarinic receptors, especially the $\mathrm{m} 2$ subtype (Valentino and Dingledine, 1981; Levey et al., 1991; Hasselmo and Bower, 1992; Scanziani et al., 1995; Kimura and Baughman, 1997; Qian and Saggau, 1997; Fernández de Sevilla and Buño, 2003; Seeger et al., 2004; Hamam et al., 2007; Kremin and Hasselmo, 2007; Salgado et al., 2007; Levy et al., 2008). For example, in the hippocampal pathway to prefrontal cortex in mice, activation of axonal $\mathrm{m} 2$ receptors suppresses postsynaptic responses (Wang and Yuan, 2009). In primate DLPFC, $\mathrm{m} 2$ receptors are mainly localized on glutamatergic axon terminals (Mrzljak et al., 1993, 1998). We found that presynaptic $m 2$ receptors were present mostly on boutons from ACC that formed excitatory synapses with spines of presumed excitatory neurons in DLPFC9. This evidence suggests that inhibitory 
A Neuropil surrounding area 32 boutons

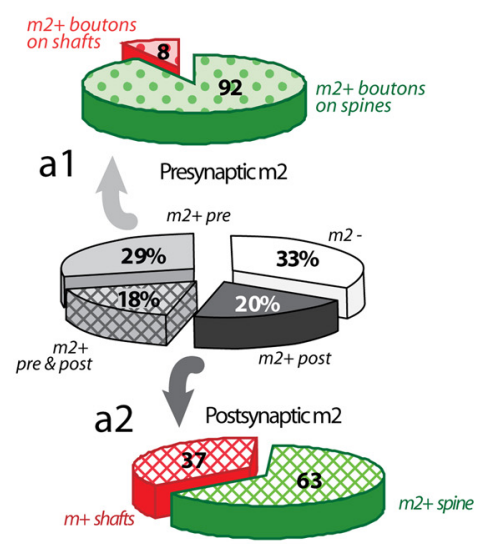

B Neuropil surrounding area 46 boutons

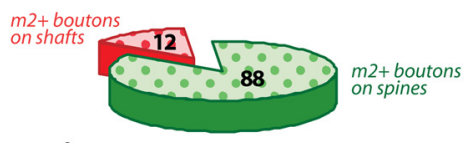

b1

Presynapticm2

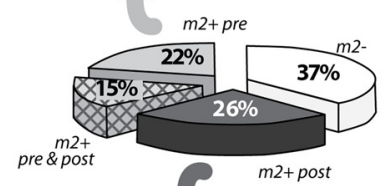

b2
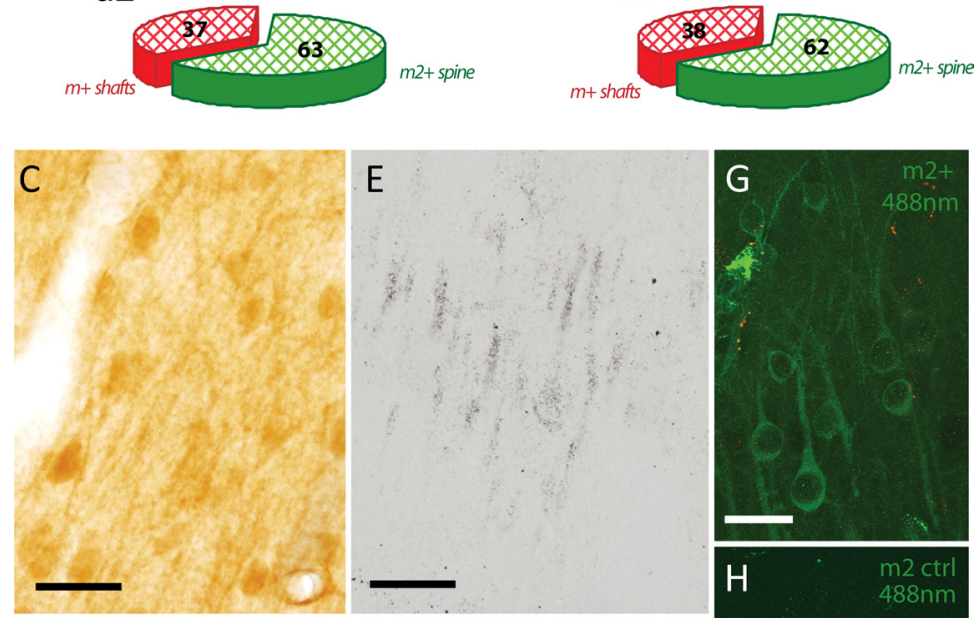

D
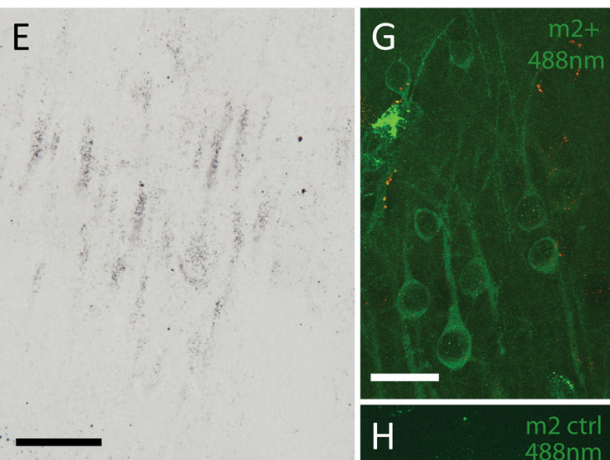

$\mathrm{F}$

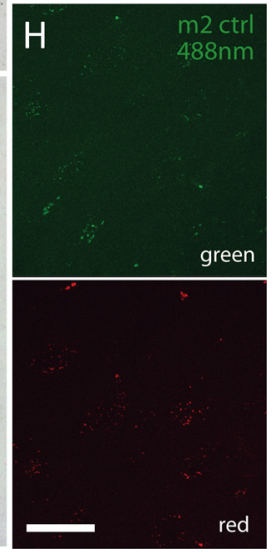

Figure 7. Distribution of $\mathrm{m} 2$ receptors in the neuropil surrounding labeled pathways in DLPFC area 9. $A, B$, The center pie charts show the overall population of synapses in the neuropil of layers II-IIlla of DLPFC area 9 surrounding tracer-labeled boutons from ACC area $32(\boldsymbol{A})$ and DLPFC area $46(\boldsymbol{B})$ and the proportions with $\mathrm{m} 2$ receptors at presynaptic (light gray) or postsynaptic sites (dark gray) only, at both sites (crosshatch), or at neither site (white). Top pie charts $(\boldsymbol{a} \mathbf{1}, \boldsymbol{b} \mathbf{1})$ show synapses in the neuropil with presynaptic $\mathrm{m}^{+}$on boutons targeting spines (excitatory, green) or dendritic shafts (inhibitory, red). Bottom pie charts $(\boldsymbol{a} \mathbf{2}, \boldsymbol{b} \mathbf{2})$ show synapses with postsynaptic $\mathrm{m} 2{ }^{+}$receptors on spines or shafts. $\mathbf{C}-\boldsymbol{H}$, Photomicrographs show specificity of immunohistochemical labeling of $\mathrm{m} 2$ receptors in layers II-III of DLPFC area 9 at the light microscope. C, Labeling of $\mathrm{m} 2$ receptors (DAB, brown) shows $\mathrm{m}^{+}$dendrites and $\mathrm{m}^{+}$somata of nonpyramidal neurons in layer $\| ; \boldsymbol{D}$, the corresponding control experiment in an adjacent section with omission of the primary antibody for $\mathrm{m} 2$ shows no evidence of immunoreactivity. $\boldsymbol{E}$, Labeling of $\mathrm{m} 2$ receptors using silver-enhanced gold-conjugated secondary antibodies shows the silhouettes of $\mathrm{m}^{+}{ }^{+}$dendrites and $\mathrm{m} 2{ }^{+}$somata (black grains); $\boldsymbol{F}$, the corresponding control experiment shows no evidence of immunoreactivity. $\boldsymbol{G}$, Confocal image stack shows $\mathrm{m} 2$ receptors labeled with green $(488 \mathrm{~nm})$ fluorescent-conjugated anti-rat $\lg G$ in layer II of area $9 ; \boldsymbol{H}$, the corresponding control experiment in an adjacent section shows no evidence of immunoreactivity in the green channel (top) or in the red channel (bottom), when the primary antibody for $\mathrm{m} 2$ was omitted. Scale bar, $25 \mu \mathrm{m}$.

cholinergic modulation during REM sleep affects primarily excitatory-to-excitatory synapses in the ACC to DLPFC9 pathway.

At the postsynaptic level, the ACC pathway showed a synaptic bias for innervating $\mathrm{m} 2^{+}$dendritic shafts of presumed inhibitory neurons in DLPFC9, whereas the pathway linking neighboring
DLPFC areas $(46 \rightarrow 9)$ showed a bias for innervating $\mathrm{m}^{+}$spines of presumed excitatory neurons. The significance of this observation is based on evidence that acetylcholine has predominantly depolarizing effects on both excitatory and inhibitory postsynaptic sites in prefrontal and other cortices (for review, see McCormick, 1989; Lucas-Meunier et al., 2003). On cortical excitatory neurons, these effects are primarily mediated through $\mathrm{m} 1$ muscarinic receptors (for review, see Levey, 1996). In addition, the excitability of cortical GABAergic neurons is increased by acetylcholine through postsynaptic muscarinic and nicotinic receptors found on dendrites of inhibitory neurons (McCormick and Prince, 1985; Pitler and Alger, 1992; Behrends and ten Bruggencate, 1993; Kawaguchi, 1997; McQuiston and Madison, 1999; Porter et al., 1999; Kondo and Kawaguchi, 2001; Gulledge et al., 2007; Disney and Aoki, 2008). In primate DLPFC, $\mathrm{m} 2$ postsynaptic receptors are found on dendrites of a subset of inhibitory neurons (Mrzljak et al., 1993, 1998), as also seen here. On balance, we estimate that acetylcholine acts on more than half of the inhibitory neurons in DLPFC 9 targeted by ACC, suggesting substantial engagement of inhibition.

During REM sleep, cholinergic neurons in the basal forebrain fire at maximal rates and acetylcholine release is high (Marrosu et al., 1995; Lee et al., 2005). The combined presynaptic and postsynaptic specializations suggest that the high level of cholinergic activity during REM sleep can suppress activity in the ACC to DLPFC pathway. These effects may drown out the weaker cholinergic-mediated excitation in the upper layers of DLPFC, as summarized in Figure 8 . In the pathway from area 46 to 9 , the prevalence of postsynaptic $m 2$ receptors on spines of excitatory neurons suggests that acetylcholine has primarily excitatory influence between two dorsolateral areas that have similar functions in working memory.

Cholinergic activity is also high in the attentive state (Himmelheber et al., 2000). However, pathway-specific cholinergic modulation can differ markedly in the awake state because the DLPFC is active and is also influenced by other neuromodulatory systems (for review, see PaceSchott and Hobson, 2002; Stenberg, 2007). Sustained activation of DLPFC neurons that represent signals maintained in working memory is primarily dependent on facilitation of recurrent excitation within DLPFC (Wang, 1999; González-Burgos et al., 2000; Constantinidis et al., 2001). Muscarinic enhancement of excitatory DLPFC pathways may strengthen task-relevant signals, as shown in physiologic studies in nonhuman primates (Croxson et al., 2011; 


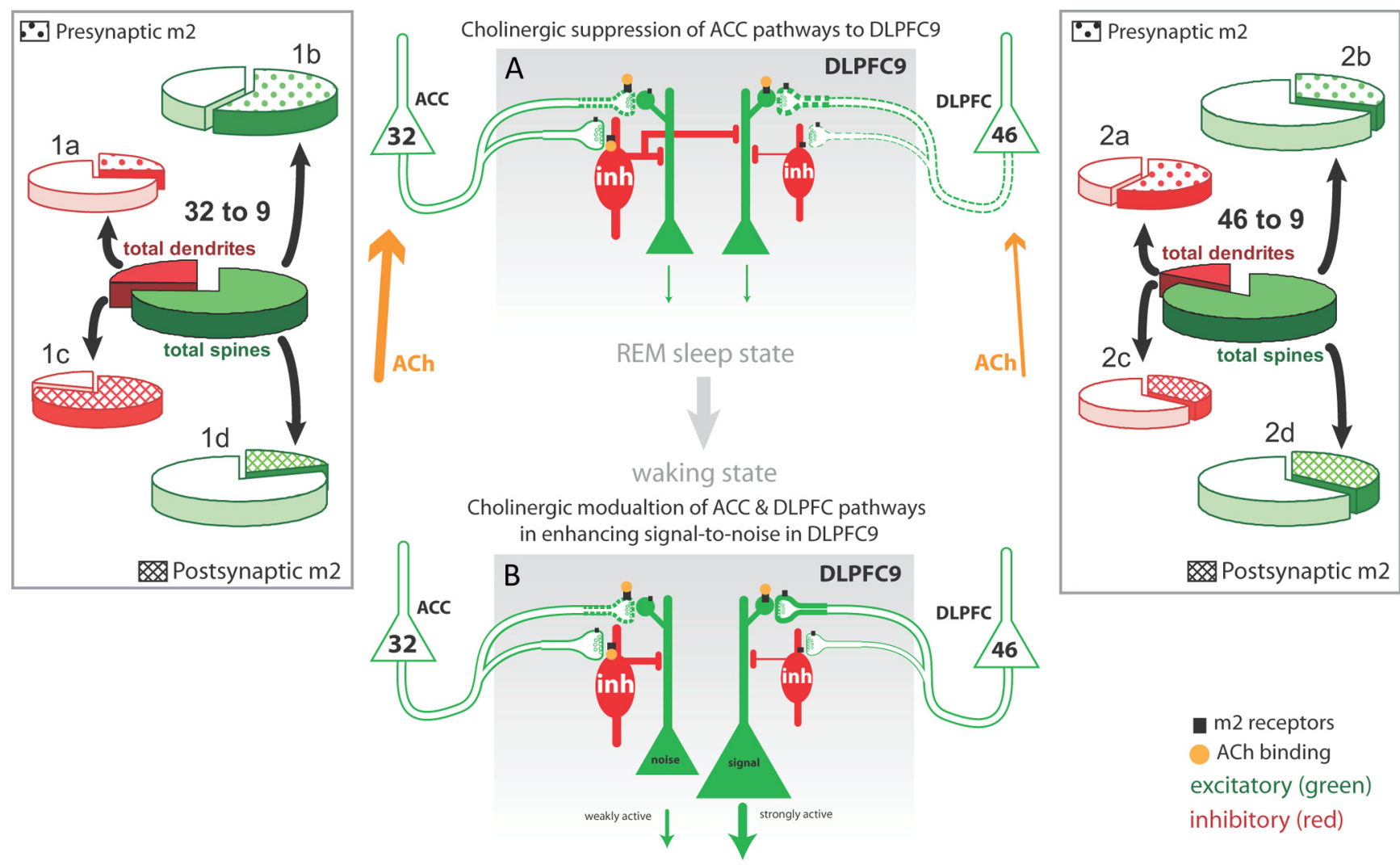

Figure 8. Summary of predominant pathway-specific interactions with $\mathrm{m} 2$ receptors. Large black squares in center (gray) panels represent higher and small black squares represent lower incidence of $\mathrm{m} 2$ receptors. Line thickness represents strength of connection, and the relative size of terminals is depicted for each pathway. The possible effects of acetylcholine (ACh, orange) in these pathways during REM sleep $(\boldsymbol{A})$ and active waking $(\boldsymbol{B})$ are summarized as follows. $\boldsymbol{A}$, In REM sleep, when cholinergic activity predominates, the ACC, which receives dense cholinergic innervation, is highly active but DLPFC, with lower cholinergic innervation, is relatively suppressed. Cholinergic suppression of ACC pathways to DLPFC area 9 (by presynaptic suppression of excitation and postsynaptic increase in inhibition) may help explain why in REM sleep the ACC does not induce excitation in DLPFC through robust excitatory pathways. The low activity of DLPFC areas and the connections interlinking them ( $46 \rightarrow 9$, dashed pathway) allows the inhibitory influence of ACC to predominate (inh, red), preserving the quiescent state of DLPFC during REM sleep. $\boldsymbol{B}$, In active waking, cholinergic levels are also high, but DLPFC is active and under other neuromodulatory influences as well. Thus, the ACC-mediated inhibition can be balanced (or masked) by excitation in a highly active DLPFC but can selectively suppress weakly active sites (i.e., the fringes of task-related active columns). During demanding cognitive tasks, ACh binding (orange dots) can enhance the excitatory effects of the DLPFC pathway to potentially sustain task-related signals within a strongly active column, while strengthening the inhibitory effects of the ACC pathway to reduce noise. Insets show the actual data of the overall proportion of synapses with presumed excitatory and inhibitory neurons formed by boutons from ACC area 32 (left inset, center) and DLPFC area 46 (right inset, center), and the respective subpopulation of synapses with presynaptic (top: $\mathbf{1 a}, \mathbf{1 b}, \mathbf{2} \boldsymbol{a}, \mathbf{2} \boldsymbol{b}$ ) or postsynaptic (bottom: $\mathbf{1 c}, \mathbf{1 d}, \mathbf{2 c}, \mathbf{2 d}$ ) $\mathrm{m} 2$ receptors.

Zhou et al., 2011). This hypothesis is consistent with prefrontalcholinergic interactions in attention and cognition (for review, see Hasselmo, 1995; Everitt and Robbins, 1997; Sarter et al., 2005). The predominance of postsynaptic muscarinic $m 2$ receptors on excitatory neurons in the DLPFC pathway $(46 \rightarrow 9)$ found here is consistent with the functional data. In contrast, our finding of large ACC synapses on inhibitory neurons in DLPFC suggests enhanced mechanisms for decreasing weaker signals that represent "noise" at the fringes of task-related active columns (Wang et al., 2004b; Medalla and Barbas, 2009, 2010). This mechanism of lateral inhibition may be further facilitated by cholinergic suppression of excitation through presynaptic $m 2$ receptors or enhancement of inhibition mediated by postsynaptic activation of targeted GABAergic neurons. The balance of excitation and inhibition in these pathways is thus likely modulated by the synaptic specificity of $\mathrm{m} 2$ cholinergic receptors, as shown here.

The synergism of the ACC and the cholinergic system in suppressing noise in DLPFC is reflected in their recruitment in tasks with high cognitive demand. The ACC is engaged when dealing with noisy conflicting signals to suppress unwanted responses (for review, see Bush et al., 2000; Paus, 2001; Schall et al., 2002; Walton et al., 2007). Similarly, acetylcholine facilitates detection of targets among distracters (Parikh et al., 2007; Furey et al., 2008; for review, see Sarter and Bruno, 1997; Dalley et al., 2004; Hasselmo and McGaughy, 2004). This ACC influence likely does not have a significant impact on the much stronger signal in adjacent active columns.

Interestingly, during REM sleep, the ACC is reactivated along with other limbic cortices, the hippocampus, and amygdala, which are also strongly modulated by acetylcholine (for review, see Kahn and Hobson, 2005; Hasselmo, 2006). Activation of this limbic circuit facilitates learning and memory (for review, see Suzuki and Eichenbaum, 2000; McGaugh, 2002; Squire et al., 2004). In particular, the ACC receives a uniquely robust projection from the hippocampus and has considerably stronger connections with the amygdala than DLPFC (Barbas and Blatt, 1995; Insausti and Muñoz, 2001; Ghashghaei et al., 2007). The potential functional disconnection between ACC and DLPFC during REM sleep may allow activity in ACC and associated limbic structures to predominate (Maquet et al., 2000; Bunce and Barbas, 2011) and mediate the sleep-related enhancement of learning and memory (for review, see Buzsáki, 2002; Schwartz and Maquet, 2002; Walker and Stickgold, 2006).

The present study provides novel evidence that the cholinergic system can differentially modulate distinct prefrontal pathways in primates through $\mathrm{m} 2$ muscarinic receptors. These findings 
suggest that pathway specificity must be considered in future physiologic studies of $\mathrm{m} 2$ and other cholinergic receptors. The role of presynaptic nicotinic receptors is particularly intriguing for enhancing neurotransmitter release, the opposite of what appears to be the case for $\mathrm{m} 2$ presynaptic receptors. In the cortex, cholinergic enhancement of glutamate release at thalamocortical synapses through nicotinic-dependent presynaptic actions is thought to increase the gain of task-relevant signals (Hsieh et al., 2000; Disney et al., 2007; for review, see Sarter et al., 2005; Hasselmo and Giocomo, 2006).

The synaptic specialization of $\mathrm{m} 2$ receptors supports a role of prefrontal-cholinergic interactions in learning and memory functions during sleep and in cognitive operations during the awake state. These distinct effects may be mediated through cholinergic enhancement of activity in the ACC pathway during REM sleep and silencing activity in DLPFC. In the awake state, acetylcholine appears to enhance activity between DLPFC areas associated with cognition and decrease noise through the pathway from ACC to DLPFC. Interestingly, hyperactivation of ACC, associated limbic areas, and the cholinergic system is linked to mood disorders accompanied by sleep disturbances (Gillin et al., 1979; for review, see Janowsky et al., 1974; Mayberg, 1997; Phillips et al., 2003). Dysfunction of $\mathrm{m} 2$ receptors, in particular, has been correlated with impaired mood regulation in depression and bipolar disorder (Comings et al., 2002; Benson et al., 2004; Wang et al., 2004a; Cannon et al., 2006, 2011). These deficits may depend on the relative engagement of distinct prefrontal pathways and specific modulation by the cholinergic system.

\section{References}

Barbas H, Blatt GJ (1995) Topographically specific hippocampal projections target functionally distinct prefrontal areas in the rhesus monkey. Hippocampus 5:511-533.

Barbas H, Ghashghaei H, Dombrowski SM, Rempel-Clower NL (1999) Medial prefrontal cortices are unified by common connections with superior temporal cortices and distinguished by input from memory-related areas in the rhesus monkey. J Comp Neurol 410:343-367.

Barbas H, Ghashghaei H, Rempel-Clower N, Xiao D (2002) Anatomic basis of functional specialization in prefrontal cortices in primates. In: Handbook of neuropsychology, Vol 7, The frontal lobes (Grafman J, ed), pp 1-27. Amsterdam: Elsevier Science.

Behrends JC, ten Bruggencate G (1993) Cholinergic modulation of synaptic inhibition in the guinea pig hippocampus in vitro: excitation of GABAergic interneurons and inhibition of GABA-release. J Neurophysiol 69: $626-629$.

Benson BE, Carson RE, Kiesewetter DO, Herscovitch P, Eckelman WC, Post RM, Ketter TA (2004) A potential cholinergic mechanism of procaine's limbic activation. Neuropsychopharmacology 29:1239-1250.

Bourne JN, Harris KM (2008) Balancing structure and function at hippocampal dendritic spines. Annu Rev Neurosci 31:47-67.

Braun AR, Balkin TJ, Wesenten NJ, Carson RE, Varga M, Baldwin P, Selbie S, Belenky G, Herscovitch P (1997) Regional cerebral blood flow throughout the sleep-wake cycle. An H2(15)O PET study. Brain 120:1173-1197.

Bunce JG, Barbas H (2011) Prefrontal pathways target excitatory and inhibitory systems in memory-related medial temporal cortices. Neuroimage 55:1461-1474.

Bush G, Luu P, Posner MI (2000) Cognitive and emotional influences in anterior cingulate cortex. Trends Cogn Sci 4:215-222.

Buzsáki G (2002) Theta oscillations in the hippocampus. Neuron 33:325340.

Cannon DM, Carson RE, Nugent AC, Eckelman WC, Kiesewetter DO, Williams J, Rollis D, Drevets M, Gandhi S, Solorio G, Drevets WC (2006) Reduced muscarinic type 2 receptor binding in subjects with bipolar disorder. Arch Gen Psychiatry 63:741-747.

Cannon DM, Klaver JK, Gandhi SK, Solorio G, Peck SA, Erickson K, Akula N, Savitz J, Eckelman WC, Furey ML, Sahakian BJ, McMahon FJ, Drevets WC (2011) Genetic variation in cholinergic muscarinic-2 receptor gene modulates $\mathrm{M}(2)$ receptor binding in vivo and accounts for reduced binding in bipolar disorder. Mol Psychiatry 16:407-418.

Comings DE, Wu S, Rostamkhani M, McGue M, Iacono WG, MacMurray JP (2002) Association of the muscarinic cholinergic 2 receptor (CHRM2) gene with major depression in women. Am J Med Genet 114:527-529.

Constantinidis C, Franowicz MN, Goldman-Rakic PS (2001) Coding specificity in cortical microcircuits: a multiple-electrode analysis of primate prefrontal cortex. J Neurosci 21:3646-3655.

Croxson PL, Kyriazis DA, Baxter MG (2011) Cholinergic modulation of a specific memory function of prefrontal cortex. Nat Neurosci 14:1510-1512.

Dalley JW, Cardinal RN, Robbins TW (2004) Prefrontal executive and cognitive functions in rodents: neural and neurochemical substrates. Neurosci Biobehav Rev 28:771-784.

DeFelipe J (1997) Types of neurons, synaptic connections and chemical characteristics of cells immunoreactive for calbindin-D28K, parvalbumin and calretinin in the neocortex. J Chem Neuroanat 14:1-19.

Disney AA, Aoki C (2008) Muscarinic acetylcholine receptors in macaque V1 are most frequently expressed by parvalbumin-immunoreactive neurons. J Comp Neurol 507:1748-1762.

Disney AA, Aoki C, Hawken MJ (2007) Gain modulation by nicotine in macaque V1. Neuron 56:701-713.

Dolleman-Van der Weel MJ, Wouterlood FG, Witter MP (1994) Multiple anterograde tracing, combining Phaseolus vulgaris leucoagglutinin with rhodamine- and biotin-conjugated dextran amine. J Neurosci Methods 51:9-21.

Dombrowski SM, Hilgetag CC, Barbas H (2001) Quantitative architecture distinguishes prefrontal cortical systems in the rhesus monkey. Cereb Cortex 11:975-988.

Erisir A, Levey AI, Aoki C (2001) Muscarinic receptor M(2) in cat visual cortex: laminar distribution, relationship to gamma-aminobutyric acidergic neurons, and effect of cingulate lesions. J Comp Neurol 441:168185.

Everitt BJ, Robbins TW (1997) Central cholinergic systems and cognition. Annu Rev Psychol 48:649-684.

Fernández de Sevilla D, Buño W (2003) Presynaptic inhibition of Schaffer collateral synapses by stimulation of hippocampal cholinergic afferent fibres. Eur J Neurosci 17:555-558.

Fiala JC (2005) Reconstruct: a free editor for serial section microscopy. J Microsc 218:52-61.

Fiala JC, Harris KM (2001a) Cylindrical diameters method for calibrating section thickness in serial electron microscopy. J Microsc 202:468-472.

Fiala JC, Harris KM (2001b) Extending unbiased stereology of brain ultrastructure to three-dimensional volumes. J Am Med Inform Assoc 8:1-16.

Furey ML, Pietrini P, Haxby JV, Drevets WC (2008) Selective effects of cholinergic modulation on task performance during selective attention. Neuropsychopharmacology 33:913-923.

Germuska M, Saha S, Fiala J, Barbas H (2006) Synaptic distinction of laminar specific prefrontal-temporal pathways in primates. Cereb Cortex 16: 865-875.

Ghashghaei HT, Barbas H (2001) Neural interaction between the basal forebrain and functionally distinct prefrontal cortices in the rhesus monkey. Neuroscience 103:593-614.

Ghashghaei HT, Hilgetag CC, Barbas H (2007) Sequence of information processing for emotions based on the anatomic dialogue between prefrontal cortex and amygdala. Neuroimage 34:905-923.

Gillin JC, Sitaram N, Duncan WC (1979) Muscarinic super-sensitivitypossible model for the sleep disturbance of primary depression. Psychiatry Res 1:17-22.

González-Burgos G, Barrionuevo G, Lewis DA (2000) Horizontal synaptic connections in monkey prefrontal cortex: an in vitro electrophysiological study. Cereb Cortex 10:82-92.

Gulledge AT, Park SB, Kawaguchi Y, Stuart GJ (2007) Heterogeneity of phasic cholinergic signaling in neocortical neurons. J Neurophysiol 97:22152229.

Hamam BN, Sinai M, Poirier G, Chapman CA (2007) Cholinergic suppression of excitatory synaptic responses in layer II of the medial entorhinal cortex. Hippocampus 17:103-113.

Hasselmo ME (1995) Neuromodulation and cortical function: modeling the physiological basis of behavior. Behav Brain Res 67:1-27.

Hasselmo ME (2006) The role of acetylcholine in learning and memory. Curr Opin Neurobiol 16:710-715. 
Hasselmo ME, Bower JM (1992) Cholinergic suppression specific to intrinsic not afferent fiber synapses in rat piriform (olfactory) cortex. J Neurophysiol 67:1222-1229.

Hasselmo ME, Giocomo LM (2006) Cholinergic modulation of cortical function. J Mol Neurosci 30:133-135.

Hasselmo ME, McGaughy J (2004) High acetylcholine levels set circuit dynamics for attention and encoding and low acetylcholine levels set dynamics for consolidation. Prog Brain Res 145:207-231.

Himmelheber AM, Sarter M, Bruno JP (2000) Increases in cortical acetylcholine release during sustained attention performance in rats. Brain Res Cogn Brain Res 9:313-325.

Hsieh CY, Cruikshank SJ, Metherate R (2000) Differential modulation of auditory thalamocortical and intracortical synaptic transmission by cholinergic agonist. Brain Res 880:51-64.

Insausti R, Muñoz M (2001) Cortical projections of the non-entorhinal hippocampal formation in the cynomolgus monkey (Macaca fascicularis). Eur J Neurosci 14:435-451.

Janowsky DS, el-Yousef MK, Davis JM (1974) Acetylcholine and depression. Psychosom Med 36:248-257.

Johnston K, Everling S (2008) Neurophysiology and neuroanatomy of reflexive and voluntary saccades in non-human primates. Brain Cogn 68: 271-283.

Kahn D, Hobson JA (2005) State-dependent thinking: a comparison of waking and dreaming thought. Conscious Cogn 14:429-438.

Kaping D, Vinck M, Hutchison RM, Everling S, Womelsdorf T (2011) Specific contributions of ventromedial, anterior cingulate, and lateral prefrontal cortex for attentional selection and stimulus valuation. PLoS Biol 9:e1001224.

Kawaguchi Y (1997) Selective cholinergic modulation of cortical GABAergic cell subtypes. J Neurophysiol 78:1743-1747.

Kimura F, Baughman RW (1997) Distinct muscarinic receptor subtypes suppress excitatory and inhibitory synaptic responses in cortical neurons. J Neurophysiol 77:709-716.

Kondo S, Kawaguchi Y (2001) Slow synchronized bursts of inhibitory postsynaptic currents $(0.1-0.3 \mathrm{~Hz})$ by cholinergic stimulation in the rat frontal cortex in vitro. Neuroscience 107:551-560.

Kremin T, Hasselmo ME (2007) Cholinergic suppression of glutamatergic synaptic transmission in hippocampal region CA3 exhibits laminar selectivity: implication for hippocampal network dynamics. Neuroscience 149:760-767.

Lee D, Rushworth MF, Walton ME, Watanabe M, Sakagami M (2007) Functional specialization of the primate frontal cortex during decision making. J Neurosci 27:8170-8173.

Lee MG, Hassani OK, Alonso A, Jones BE (2005) Cholinergic basal forebrain neurons burst with theta during waking and paradoxical sleep. J Neurosci 25:4365-4369.

Levey AI (1996) Muscarinic acetylcholine receptor expression in memory circuits: implications for treatment of Alzheimer disease. Proc Natl Acad Sci U S A 93:13541-13546.

Levey AI, Kitt CA, Simonds WF, Price DL, Brann MR (1991) Identification and localization of muscarinic acetylcholine receptor proteins in brain with subtype-specific antibodies. J Neurosci 11:3218-3226.

Levey AI, Edmunds SM, Hersch SM, Wiley RG, Heilman CJ (1995) Light and electron microscopic study of $\mathrm{m} 2$ muscarinic acetylcholine receptor in the basal forebrain of the rat. J Comp Neurol 351:339-356.

Levy RB, Reyes AD, Aoki C (2008) Cholinergic modulation of local pyramid-interneuron synapses exhibiting divergent short-term dynamics in rat sensory cortex. Brian Res 1215:97-104.

Lewis DA (1991) Distribution of choline acetyltransferase-immunoreactive axons in monkey frontal cortex. Neuroscience 40:363-374.

Lidow MS, Gallager DW, Rakic P, Goldman-Rakic PS (1989) Regional differences in the distribution of muscarinic cholinergic receptors in the macaque cerebral cortex. J Comp Neurol 289:247-259.

Lucas-Meunier E, Fossier P, Baux G, Amar M (2003) Cholinergic modulation of the cortical neuronal network. Pflugers Arch 446:17-29.

Maquet P, Péters J, Aerts J, Delfiore G, Degueldre C, Luxen A, Franck G (1996) Functional neuroanatomy of human rapid-eye-movement sleep and dreaming. Nature 383:163-166.

Maquet P, Laureys S, Peigneux P, Fuchs S, Petiau C, Phillips C, Aerts J, Del Fiore G, Degueldre C, Meulemans T, Luxen A, Franck G, Van Der Linden M, Smith C, Cleeremans A (2000) Experience-dependent changes in cerebral activation during human REM sleep. Nat Neurosci 3:831-836.
Marrosu F, Portas C, Mascia MS, Casu MA, F á M, Giagheddu M, Imperato A, Gessa GL (1995) Microdialysis measurement of cortical and hippocampal acetylcholine release during sleep-wake cycle in freely moving cats. Brain Res 2:329-332.

Mayberg HS (1997) Limbic-cortical dysregulation: a proposed model of depression. J Neuropsychiatry Clin Neurosci 9:471-481.

McCormick DA (1989) Acetylcholine: distribution, receptors, and actions. Semin Neurosci 1:91-101.

McCormick DA, Prince DA (1985) Two types of muscarinic response to acetylcholine in mammalian cortical neurons. Proc Natl Acad Sci U S A 82:6344-6348.

McGaugh JL (2002) Memory consolidation and the amygdala: a systems perspective. Trends Neurosci 25:456.

McQuiston AR, Madison DV (1999) Muscarinic receptor activity has multiple effects on the resting membrane potentials of CA1 hippocampal interneurons. J Neurosci 19:5693-5702.

Medalla M, Barbas H (2006) Diversity of laminar connections linking periarcuate and lateral intraparietal areas depends on cortical structure. Eur J Neurosci 23:161-179.

Medalla M, Barbas H (2009) Synapses with inhibitory neurons differentiate anterior cingulate from dorsolateral prefrontal pathways associated with cognitive control. Neuron 61:609-620.

Medalla M, Barbas H (2010) Anterior cingulate synapses in prefrontal areas 10 and 46 suggest differential influence in cognitive control. J Neurosci 30:16068-16081.

Medalla M, Lera P, Feinberg M, Barbas H (2007) Specificity in inhibitory systems associated with prefrontal pathways to temporal cortex in primates. Cereb Cortex 17 [Suppl 1]:i136-i150.

Mesulam MM, Rosen AD, Mufson EJ (1984) Regional variations in cortical cholinergic innervation: chemoarchitectonics of acetylcholinesterasecontaining fibers in the macaque brain. Brain Res 311:245-258.

Mesulam MM, Hersh LB, Mash DC, Geula C (1992) Differential cholinergic innervation within functional subdivisions of the human cerebral cortex: a choline acetyltransferase study. J Comp Neurol 318:316-328.

Mrzljak L, Levey AI, Goldman-Rakic PS (1993) Association of m1 and m2 muscarinic receptor proteins with asymmetric synapses in the primate cerebral cortex: morphological evidence for cholinergic modulation of excitatory neurotransmission. Proc Natl Acad Sci U S A 90:5194-5198.

Mrzljak L, Levey AI, Belcher S, Goldman-Rakic PS (1998) Localization of the $\mathrm{m} 2$ muscarinic acetylcholine receptor protein and mRNA in cortical neurons of the normal and cholinergically deafferented rhesus monkey. J Comp Neurol 390:112-132.

Muly EC, Senyuz M, Khan ZU, Guo JD, Hazra R, Rainnie DG (2009) Distribution of D-1 and D-5 dopamine receptors in the primate and rat basolateral amygdala. Brain Struct Funct 213:375-393.

Murthy VN, Sejnowski TJ, Stevens CF (1997) Heterogeneous release properties of visualized individual hippocampal synapses. Neuron 18: $599-612$.

Muzur A, Pace-Schott EF, Hobson JA (2002) The prefrontal cortex in sleep. Trends Cogn Sci 6:475-481.

Nimchinsky EA, Sabatini BL, Svoboda K (2002) Structure and function of dendritic spines. Annu Rev Physiol 64:313-353.

Pace-Schott EF, Hobson JA (2002) The neurobiology of sleep: genetics, cellular physiology and subcortical networks. Nat Rev Neurosci 3:591-605.

Parikh V, Kozak R, Martinez V, Sarter M (2007) Prefrontal acetylcholine release controls cue detection on multiple timescales. Neuron 56:141154.

Paus T (2001) Primate anterior cingulate cortex: where motor control, drive and cognition interface. Nat Rev Neurosci 2:417-424.

Peters A, Palay SL, Webster HD (1991) The fine structure of the nervous system. Neurons and their supporting cells. New York: Oxford UP.

Petrides M (2000) The role of the mid-dorsolateral prefrontal cortex in working memory. Exp Brain Res 133:44-54.

Phillips ML, Drevets WC, Rauch SL, Lane R (2003) Neurobiology of emotion perception II. Implications for major psychiatric disorders. Biol Psychiatry $54: 515-528$.

Pitler TA, Alger BE (1992) Cholinergic excitation of GABAergic interneurons in the rat hippocampal slice. J Physiol 450:127-142.

Porter JT, Cauli B, Tsuzuki K, Lambolez B, Rossier J, Audinat E (1999) Selective excitation of subtypes of neocortical interneurons by nicotinic receptors. J Neurosci 19:5228-5235.

Qian J, Saggau P (1997) Presynaptic inhibition of synaptic transmission in 
the rat hippocampus by activation of muscarinic receptors: involvement of presynaptic calcium influx. Br J Pharmacol 122:511-519.

Reiner A, Veenman CL, Medina L, Jiao Y, Del Mar N, Honig MG (2000) Pathway tracing using biotinylated dextran amines. J Neurosci Methods 103:23-37.

Rosene DL, Roy NJ, Davis BJ (1986) A cryoprotection method that facilitates cutting frozen sections of whole monkey brains from histological and histochemical processing without freezing artifact. J Histochem Cytochem 34:1301-1315.

Rushworth MF, Noonan MP, Boorman ED, Walton ME, Behrens TE (2011) Frontal cortex and reward-guided learning and decision-making. Neuron 70:1054-1069.

Salgado H, Bellay T, Nichols JA, Bose M, Martinolich L, Perrotti L, Atzori M (2007) Muscarinic M2 and M1 receptors reduce GABA release by $\mathrm{Ca}^{2+}$ channel modulation through activation of PI3K/ $/ \mathrm{Ca}^{2+}$-independent and PLC/Ca ${ }^{2+}$-dependent PKC. J Neurophysiol 98:952-965.

Sarter M, Bruno JP (1997) Cognitive functions of cortical acetylcholine: toward a unifying hypothesis. Brain Res Brain Res Rev 23:28-46.

Sarter M, Hasselmo ME, Bruno JP, Givens B (2005) Unraveling the attentional functions of cortical cholinergic inputs: interactions between signal-driven and cognitive modulation of signal detection. Brain Res Brain Res Rev 48:98-111.

Scanziani M, Gahwiler BH, Thompson SM (1995) Presynaptic inhibition of excitatory synaptic transmission by muscarinic and metabotropic glutamate receptor activation in the hippocampus: are $\mathrm{Ca}^{2+}$ channels involved? Neuropharmacology 34:1549-1557.

Schall JD, Stuphorn V, Brown JW (2002) Monitoring and control of action by the frontal lobes. Neuron 36:309-322.

Schwartz S, Maquet P (2002) Sleep imaging and the neuro-psychological assessment of dreams. Trends Cogn Sci 6:23-30.

Seeger T, Fedorova I, Zheng F, Miyakawa T, Koustova E, Gomeza J, Basile AS, Alzheimer C, Wess J (2004) M2 muscarinic acetylcholine receptor knock-out mice show deficits in behavioral flexibility, working memory, and hippocampal plasticity. J Neurosci 24:10117-10127.

Squire LR, Stark CE, Clark RE (2004) The medial temporal lobe. Annu Rev Neurosci 27:279-306.

Stenberg D (2007) Neuroanatomy and neurochemistry of sleep. Cell Mol Life Sci 10:1187-1204.

Suzuki WA, Eichenbaum H (2000) The neurophysiology of memory. Ann N Y Acad Sci 911:175-191.

Tian S, Qi H, Wang J, Cai J, Ma Y (2002) Differential amplitude modulation of auditory evoked cortical potentials associated with brain state in the freely moving rhesus monkey. Neurosci Lett 331:159-162.

Tian S, Hu B, Li P, Zhao Z, Ouyang X, Zhou S, Ma Y (2006) Assessing functioning of the prefrontal cortical subregions with auditory evoked potentials in sleep-wake cycle. Neurosci Lett 393:7-11.

Tong G, Jahr CE (1994) Multivesicular release from excitatory synapses of cultured hippocampal neurons. Neuron 12:51-59.

Valentino RJ, Dingledine R (1981) Presynaptic inhibitory effect of acetylcholine in the hippocampus. J Neurosci 1:784-792.

Veenman CL, Reiner A, Honig MG (1992) Biotinylated dextran amine as an anterograde tracer for single- and double-labeling studies. J Neurosci Methods 41:239-254.

Walker MP, Stickgold R (2006) Sleep, memory, and plasticity. Annu Rev Psychol 57:139-166.

Walker MP, Stickgold R, Alsop D, Gaab N, Schlaug G (2005) Sleepdependent motor memory plasticity in the human brain. Neuroscience 133:911-917.

Walton ME, Croxson PL, Behrens TE, Kennerley SW, Rushworth MF (2007) Adaptive decision making and value in the anterior cingulate cortex. Neuroimage 36 [Suppl 2]:T142-T154.

Wang JC, Hinrichs AL, Stock H, Budde J, Allen R, Bertelsen S, Kwon JM, Wu W, Dick DM, Rice J, Jones K, Nurnberger JI Jr, Tischfield J, Porjesz B, Edenberg HJ, Hesselbrock V, Crowe R, Schuckit M, Begleiter H, Reich T, Goate AM, Bierut LJ (2004a) Evidence of common and specific genetic effects: association of the muscarinic acetylcholine receptor M2 (CHRM2) gene with alcohol dependence and major depressive syndrome. Hum Mol Genet 13:1903-1911.

Wang L, Yuan LL (2009) Activation of M2 muscarinic receptors leads to sustained suppression of hippocampal transmission in the medial prefrontal cortex. J Physiol 587:5139-5147.

Wang XJ (1999) Synaptic basis of cortical persistent activity: the importance of NMDA receptors to working memory. J Neurosci 19:9587-9603.

Wang XJ, Tegnér J, Constantinidis C, Goldman-Rakic PS (2004b) Division of labor among distinct subtypes of inhibitory neurons in a cortical microcircuit of working memory. Proc Natl Acad Sci U S A 101:1368-1373.

Zhou X, Qi XL, Douglas K, Palaninathan K, Kang HS, Buccafusco JJ, Blake DT, Constantinidis C (2011) Cholinergic modulation of working memory activity in primate prefrontal cortex. J Neurophysiol 106:2180-2188.

Zikopoulos B, Barbas H (2006) Prefrontal projections to the thalamic reticular nucleus form a unique circuit for attentional mechanisms. J Neurosci 26:7348-7361.

Zikopoulos B, Barbas H (2007) Parallel driving and modulatory pathways link the prefrontal cortex and thalamus. PLoS One 2:e848.

Zikopoulos B, and Barbas H (2012) Pathways for emotions and attention converge on the thalamic reticular nucleus in primates. J Neurosci 32: $5338-5350$. 